\title{
Ice nucleating particles over the Eastern Mediterranean measured by unmanned aircraft systems
}

\author{
Jann Schrod $^{1}$, Daniel Weber ${ }^{1}$, Jaqueline Drücke ${ }^{1}$, Christos Keleshis $^{2}$, Michael Pikridas ${ }^{2}$, Martin Ebert $^{3}$, \\ Bojan Cvetkovic $^{4}$, Slobodan Nickovic ${ }^{4}$, Eleni Marinou ${ }^{5,6}$, Holger Baars ${ }^{7}$, Albert Ansmann ${ }^{7}$, Mihalis Vrekoussis ${ }^{2,8,9}$, \\ Nikos Mihalopoulos $^{2,10}$, Jean Sciare ${ }^{2}$, Joachim Curtius ${ }^{1}$, and Heinz G. Bingemer ${ }^{1}$ \\ ${ }^{1}$ Institute for Atmospheric and Environmental Sciences, Goethe University Frankfurt, 60438 Frankfurt am Main, Germany \\ ${ }^{2}$ Energy, Environment and Water Research Center, The Cyprus Institute, Nicosia, 2121 Aglantziá, Cyprus \\ ${ }^{3}$ Institute for Applied Geosciences, Technical University of Darmstadt, 64287 Darmstadt, Germany \\ ${ }^{4}$ Republic Hydrometeorological Service of Serbia, 11000 Belgrade, Serbia \\ ${ }^{5}$ Institute for Astronomy, Astrophysics, Space Applications and Remote Sensing, National Observatory of Athens, \\ 15236 Athens, Greece \\ ${ }^{6}$ Department of Physics, Aristotle University of Thessaloniki, 54124 Thessaloniki, Greece \\ ${ }^{7}$ Leibniz Institute for Tropospheric Research, 04318 Leipzig, Germany \\ ${ }^{8}$ Institute of Environmental Physics and Remote Sensing, IUP, University of Bremen, 28359 Bremen, Germany \\ ${ }^{9}$ Center of Marine Environmental Sciences, MARUM, University of Bremen, 28359 Bremen, Germany \\ ${ }^{10}$ Institute for Environmental Research and Sustainable Development, National Observatory of Athens, 15236 Athens, Greece
}

Correspondence to: Jann Schrod (schrod@iau.uni-frankfurt.de)

Received: 5 December 2016 - Discussion started: 7 December 2016

Revised: 28 February 2017 - Accepted: 20 March 2017 - Published: 12 April 2017

\begin{abstract}
During an intensive field campaign on aerosol, clouds, and ice nucleation in the Eastern Mediterranean in April 2016, we measured the abundance of ice nucleating particles (INPs) in the lower troposphere from unmanned aircraft systems (UASs). Aerosol samples were collected by miniaturized electrostatic precipitators onboard the UASs at altitudes up to $2.5 \mathrm{~km}$. The number of INPs in these samples, which are active in the deposition and condensation modes at temperatures from -20 to $-30^{\circ} \mathrm{C}$, were analyzed immediately after collection on site using the ice nucleus counter FRIDGE (FRankfurt Ice nucleation Deposition freezinG Experiment). During the 1-month campaign, we encountered a series of Saharan dust plumes that traveled at several kilometers' altitude. Here we present INP data from 42 individual flights, together with aerosol number concentrations, observations of lidar backscattering, dust concentrations derived by the dust transport model DREAM (Dust Regional Atmospheric Model), and results from scanning electron microscopy. The effect of the dust plumes is reflected by the coincidence of INPs with the particulate matter (PM), the lidar signal, and the predicted dust mass of the model. This
\end{abstract}

suggests that mineral dust or a constituent related to dust was a major contributor to the ice nucleating properties of the aerosol. Peak concentrations of above 100 INPs std $\mathrm{L}^{-1}$ were measured at $-30{ }^{\circ} \mathrm{C}$. The INP concentration in elevated plumes was on average a factor of 10 higher than at ground level. Since desert dust is transported for long distances over wide areas of the globe predominantly at several kilometers' altitude, we conclude that INP measurements at ground level may be of limited significance for the situation at the level of cloud formation.

\section{Introduction}

Ice nucleating particles (INPs) act as a seed surface for water vapor and liquid water to enable the emergence and growth of ice crystals in the atmosphere. The process of ice nucleation can occur by immersion, condensation, deposition, or contact freezing (for a detailed explanation, see Vali et al., 2015). Despite their low abundance in the atmosphere, INPs are crucial for the evolution of ice in clouds. Without their existence, 
the ice phase in clouds would solely arise from homogeneous ice nucleation at temperatures below about $-36^{\circ} \mathrm{C}$. In the presence of INPs, water freezes at much higher temperatures by heterogeneous ice nucleation, thus affecting the formation of clouds, precipitation, and climate. It is a well-known fact that the ice phase plays a key role in the development of precipitation via the Wegener-Bergeron-Findeisen process. Mülmenstädt et al. (2015) found that precipitation especially over continental regions and the midlatitude oceans is mainly produced via the ice phase. However, the abundance and distribution of INPs are largely unknown (DeMott et al., 2010). Partly due to this fact, the estimates of radiative climate forcing presented in the IPCC AR5 show the largest error bars and the lowest levels of confidence in the category of cloud adjustments due to aerosol (IPCC, 2013).

Many topics in ice nucleation are not yet investigated to a satisfying degree: e.g., the abundance and vertical profile of INPs as a function of cloud nucleation conditions (temperature and supersaturation), the aerosol particle spectrum, as well as the nature, source, and properties (such as morphology, chemical composition, and degree of coating) of individual INPs. Which physical and chemical properties favor the formation of ice on the surface of an aerosol particle still remains a field of intense research. Furthermore, field data of INPs are very limited in a number of ways. The number of observations is still relatively small. These observations cover only a few selected geographical locations and the bulk comes from the United States of America or Europe. Very few to no measurements are available for the vast majority of other regions of the world (or even whole continents and oceans). Although from laboratory experiments a number of aerosol species are identified as being capable of nucleating ice, rather little is known about their importance in the real atmosphere. Primary biological particles such as certain bacteria like Pseudomonas syringae show a high potential to nucleate at high temperatures (Schnell and Vali, 1973; Maki et al., 1974; Vali et al., 1976; Wex et al., 2015). However, little is known about their atmospheric abundance, which appears to be low. Whether or not they have an actual global-scale impact on ice formation in mixed-phase clouds is still unclear (Hoose et al., 2010). Recently, O'Sullivan et al. (2015) proposed that nanometer-scale fragments of biogenic particles, which appear to be far more numerous than the supermicron parent species, may indeed play an important role for cloud glaciation processes, especially at temperatures above $-20^{\circ} \mathrm{C}$. While these biological nanoparticles are unlikely to be directly aerosolized in great numbers from the surface, they may be mobilized mixed together with soil dust particles. O'Sullivan et al. (2016) demonstrated that nanoscale particles from the common fungus Fusarium avenaceum adsorb easily to kaolinite and transfer their high ice nucleating activity to the clay in the process. They found that even after multiple water washings, the mixture preserved a high ice activity. Yet the absolute source strengths of such nanometer-scale biological particles, released into the atmosphere, still need to be determined.

On the other hand, mineral dust particles originating from the deserts have been postulated for a long time (Wegener, 1911) to be major contributors to atmospheric INPs. Mineral dust particles have consistently been identified worldwide as INPs in many studies (e.g., Kumai, 1951; Isono, 1955; DeMott et al., 2003b; Pratt et al., 2009; Prenni et al., 2009b), usually at temperatures below $-20^{\circ} \mathrm{C}$. Many of the earlier field studies conclude that dust has ice nucleating properties by circumstantial reasoning, i.e., from the correlation of dust parameters with INP abundance. The advanced coupling of INP measurements to electron microscopy or to mass spectrometry, which allows the identification of single nucleating particles, again demonstrated that mineral dust is a major constituent of INPs but that a significant biological INP compound can be present too (Pratt et al., 2009; Prenni et al., 2009 b). INP concentrations measured within a dust layer can reach up to $1000 \mathrm{~L}^{-1}$ (DeMott et al., 2003a). Once mobilized by high surface winds in arid and semiarid regions of the world, mineral dust particles can travel up to several thousands of kilometers (Prospero, 1999). Hence, regions that are far away from the desert can still be influenced by mineral dust due to efficient long-distance transport. Liu et al. (2008) have shown the first height-resolved global distribution of dust aerosol based on lidar measurements of CALIPSO. They found northern hemispheric spring to be the most active dust season, with $12 \%$ of the areas between $0^{\circ}$ and $60^{\circ} \mathrm{N}$ to be influenced at least half the time. In general the vertical extent of the mineral dust was found to be strongly dependent on season and source region. Peak dust layers were found to be between 2 and $3 \mathrm{~km}$ in summer and 1 and $2 \mathrm{~km}$ in the other seasons. The regions of North Africa and the Arabian Peninsula were found to be the most persistent sources of mineral dust. Transatlantic transport of African dust was seen all year, with a significant amount of dust transported in the free troposphere in layers above $2 \mathrm{~km}$ in summer. In winter most dust was transported below $2 \mathrm{~km}$. In summary, existing climatologies demonstrate that mineral dust is mainly transported in the lowest few kilometers of the atmosphere. Nonetheless, to date, most INP measurements are made at ground level and not at elevations where clouds are actually formed.

These findings strongly emphasize the need for more measurements of INPs above ground level. Yet achieving INP measurements in free-tropospheric air masses is challenging and usually requires substantial effort. For over a decade, large research aircraft equipped with continuous-flow diffusion chambers (CFDCs) have been used to measure INP concentration and composition in the free troposphere (e.g., Rogers et al., 2001a, b; DeMott et al., 2003a; Cziczo et al., 2004; Prenni et al., 2009a). So far, a lightweight and easy-touse alternative solution has been lacking. The unmanned aircraft systems (UASs)-based offline INP measurement technique presented in this study may be able to fill this gap. 
However, admittedly, this technique lacks the capability of high time resolution and large spatial coverage as can be expected with a CFDC-aircraft combination. With their easy commercial availability, high flexibility, and light dimensions, UASs theoretically offer the potential of more frequent or even regular measurements of INPs in many different locations all around the world. This could enhance the number of global INP observations drastically, therewith shedding light on many regions of the world where such data are missing. While the UASs used here could not be operated in the altitude regions where it is cold enough for INP activation to take place, our free-tropospheric measurements are likely to be much more representative of the atmospheric conditions of ice formation in clouds than ground-based measurements. Larger drones (e.g., global hawk) might one day even be offering the space for online measuring CFDCs, although many of the advantages of the light and easy setup of smaller-sized UASs would be lost.

The scientific community in various fields has already identified UAS technology as a great platform for new approaches. The diverse areas of investigations with UASs cover remote sensing (Colomina et al., 2014; Watts et al., 2012), meteorological profiling (Holland et al., 1992; Reuder et al., 2009), and greenhouse gases (McGonigle et al., 2008), to name but a few. More recently, vertical profiles and distributions of aerosol particles (Corrigan et al., 2008; Bates et al., 2013) and cloud microphysical parameters (Roberts et al., 2007; Jensen et al., 2012) have been measured with UASs, highlighting the versatility and the immense potential of UAS-operated observations, especially for atmospheric sciences. However, to our knowledge, no measurements of INPs based on UASs have been performed or published to this day.

The method we present here to measure INPs from the UAS is based on the offline ice nucleus counter FRIDGE (FRankfurt Ice nucleation Deposition freezinG Experiment) (Schrod et al., 2016). FRIDGE couples the sampling of INPs onboard the UAS by electrostatic precipitation of aerosol particles onto substrates with the subsequent analysis of the substrates in the isostatic diffusion chamber FRIDGE. The presence of INPs is detected by growing ice crystals on the substrate. No information on the nature of the INPs is derived. The question whether the ice nucleation happened on a dust particle or a biological particle mixed with the dust remains open. An advanced version of our method that couples INP detection by FRIDGE with subsequent electron microscopy analysis of the individual active INP was not applied here, due to the heavy loading of the samples.

From 27 March to 28 April 2016, a joint field campaign of Ice Nuclei Research Unit (INUIT) and the EU projects BACCHUS (Impact of Biogenic versus Anthropogenic emissions on Clouds and Climate: towards a Holistic UnderStanding) and ACTRIS (Aerosols, Clouds, and Trace gases Research InfraStructure) took place at a remote location in Cyprus in the Eastern Mediterranean Sea, an environment that is fre- quently affected by desert dust. The campaign objectives were centered on studying aerosol and cloud properties, with a special interest in ice nucleation. This study is the first in a series of publications to come from this experiment. For more information about the campaign itself and a more detailed analysis of the meteorological situation, we refer to an upcoming overview paper, which will also cover simultaneous ground-based measurements of INPs by other groups and instruments (Kanji et al., 2017).

\section{Methods}

\subsection{Site description and campaign setup}

The island of Cyprus is located in the Mediterranean Sea approximately $100 \mathrm{~km}$ south of the Turkish mainland, $100 \mathrm{~km}$ west of the Syrian coast and $300 \mathrm{~km}$ north of the Egyptian coast. This geographical location with the close proximity of the Sahara Desert in the southwest and the deserts of the Arabian Peninsula in the southeast favors a regular encounter of mineral-dust-rich air masses. Particularly during spring time and early summer, depressions south of the Atlas Mountains mobilize dust and inject it into the westerly flow (Moulin et al., 2008; Querol et al., 2009; Pey et al., 2013). Israelevich et al. (2001) identified the Chad Basin at $16^{\circ} \mathrm{N}, 16^{\circ} \mathrm{E}$ and the Eljouf Basin in Mauritania at $5^{\circ} \mathrm{W}, 19^{\circ} \mathrm{N}$ as the major source areas of dust for the Mediterranean Basin. Furthermore, Cyprus is influenced by marine aerosol and by anthropogenic emissions from southeastern Europe and the Middle East. The exposure to these highly variable emission sources favored our choice of this location for an intensive campaign on aerosol properties and ice nucleation. During the campaign three independent measurement sites were operated. $\mathrm{Li}$ dar measurements were performed in Nicosia $\left(35^{\circ} 08^{\prime} 26^{\prime \prime} \mathrm{N}\right.$, $33^{\circ} 22^{\prime} 52^{\prime \prime} \mathrm{E} ; 181 \mathrm{~m}$ a.s.l.). At the Cyprus Atmospheric Observatory (CAO) in the foothills of Troödos Mountains (Agia Marina Xyliatou, $35^{\circ} 02^{\prime} 19^{\prime \prime} \mathrm{N}, 33^{\circ} 03^{\prime} 28^{\prime \prime} \mathrm{E}$; $532 \mathrm{~m}$ a.s.l.; http://www.cyi.ac.cy/index.php/cao.html), aerosol properties and INPs were measured. The UAS-based observations were carried out $6.5 \mathrm{~km}$ north of $\mathrm{CAO}$ at the Cyprus Institute UAS airfield (Orounda, $35^{\circ} 05^{\prime} 42^{\prime \prime} \mathrm{N}, 33^{\circ} 04^{\prime} 53^{\prime \prime} \mathrm{E}$; $327 \mathrm{~m}$ a.s.l.; http://www.cyi.ac.cy/index.php/usrl.html). This paper focuses on the INP measurements conducted on the UAS.

\subsection{Meteorological conditions}

During the campaign the Eastern Mediterranean was mainly under westerly flow, as indicated by the contours of the monthly mean stream function at $500 \mathrm{hPa}$ (Fig. 1a). This flow meandered according to the eastward propagation of troughs and ridges with periods of several days. At sea surface level, pressure gradients over the Eastern Mediterranean were mostly weak (Fig. 1b). The days of 27 to 30 March in Cyprus were characterized by cold, cyclonic conditions 

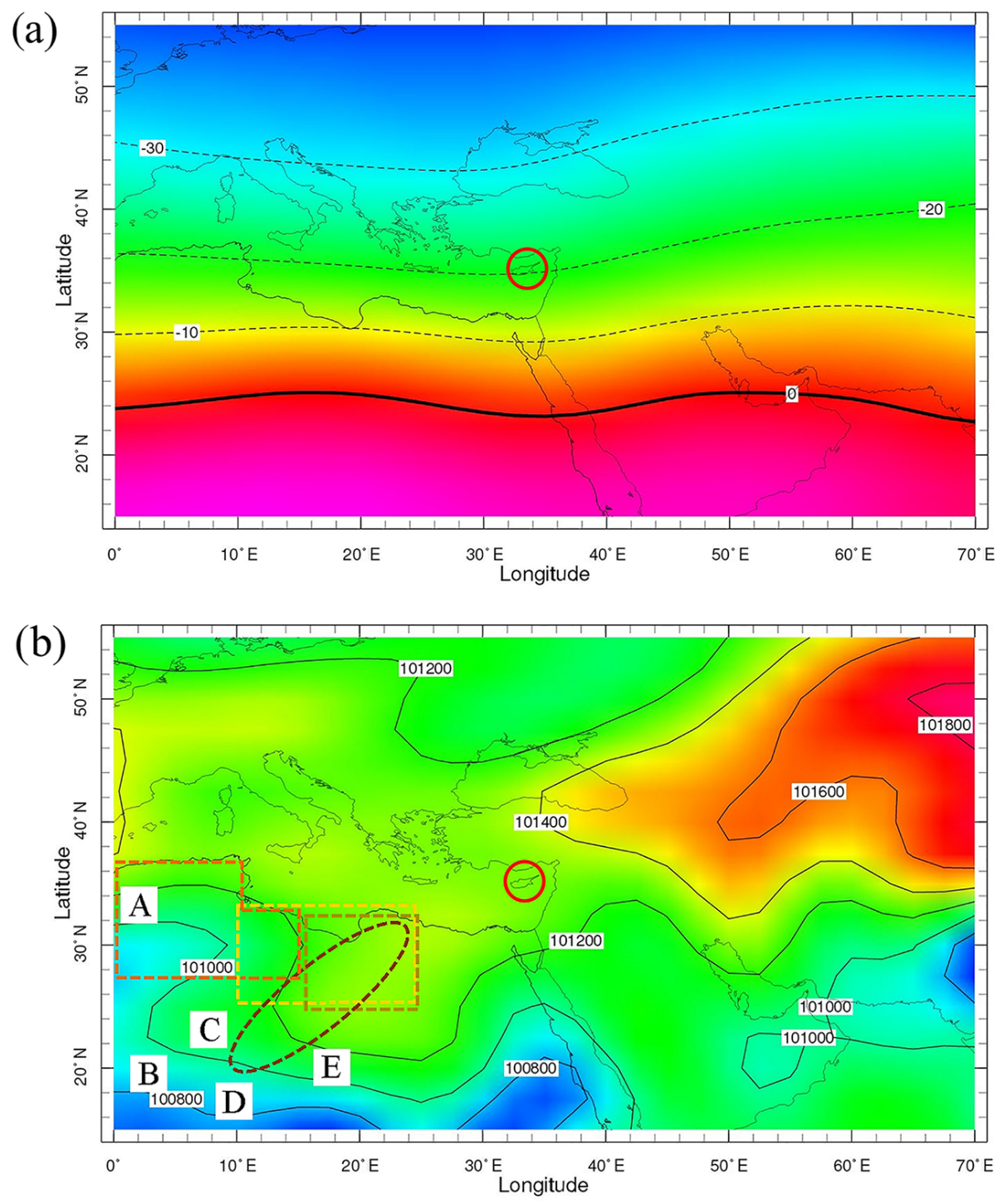

Figure 1. (a) Mean stream function at $500 \mathrm{hPa}$ (range: -40 (blue) to 10 (purple) $\mathrm{m}^{2} \mathrm{~s}^{-1}$ ). (b) Mean sea level pressure (range: 100600 (blue) to 102000 (purple) Pa) in April 2016 for the Eastern Mediterranean (IRI 2016). The island of Cyprus is indicated by a red circle. Letters A to E in the lower panel refer to North African orography: A - foothills of the Atlas Mountains; B - Adrar Plateau; C - Ahaggar Mountains; D - Aïr massif; and E - Tibesti Mountains. The dashed rectangles and ellipse refer to dust source regions for this campaign (cf. Sect. 3.1 and Movie S1 in the Supplement)

and 1 to 8 April by warm, anticyclonic conditions. A lowpressure system that was cut off the major trough over Spain on 6 April traveled slowly eastward along the North African coastline and the Eastern Mediterranean Sea and over Cyprus (12 to 13 April) towards Syria, where it dissipated. On 14 to 20 April, anticyclonic conditions prevailed in Cyprus with a westerly flow of warm air; on 21 to 27 April, again a cyclonic pattern with predominantly warm southwesterly air was present. The Movie S1 gives a more detailed view of atmospheric transport as seen by DREAM (Dust Regional Atmospheric Model) (cf. Sects. 2.8 and 3.1), using the dust load as a tracer for atmospheric motion during the campaign.
Figure 2 shows the meteorological conditions at CAO during the campaign. During the first 2 weeks of the campaign the daily maximum temperature was increasing and relative humidity was decreasing. This was followed by a strong increase in humidity on 9 April and a period of high humidity and lower temperatures with a few millimeters of rain on 12 April. Days with rising temperatures and decreasing humidity conditions then followed. The local wind direction at $\mathrm{CAO}$ was from the western sector nearly $70 \%$ of the time with wind speeds usually below $5 \mathrm{~ms}^{-1}$ (Figs. 2c and 3). Figure 4 shows the 10-day backward trajectories ending at $1000 \mathrm{~m}$ above ground at Orounda. The model used here is 


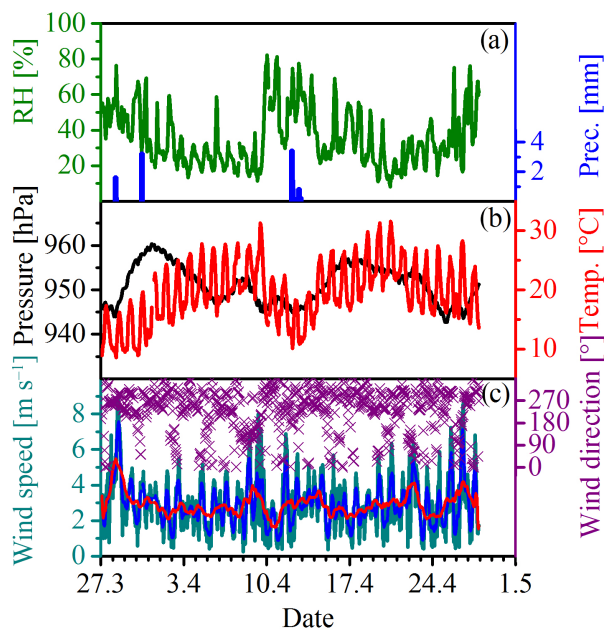

Figure 2. One-hour averages of meteorological parameters (a relative humidity (green) and precipitation (blue); $\mathbf{b}$ unreduced pressure (black) and temperature (red); c wind direction (purple crosses) and speed (cyan) and its running means of $6 \mathrm{~h}$ (blue) and $24 \mathrm{~h}$ (red)) during the campaign measured at CAO by the Department of Labour Inspection of Cyprus (DLI).

the Hybrid Single Particle Lagrangian Integrated Trajectory Model (HYSPLIT; Stein et al., 2015; Rolph, 2016). Trajectories were calculated at 03:00, 06:00, and 09:00 UTC, in phase with most UAS flights which took place from 04:00 to 12:00 UTC. The vast majority of air masses that reached the UAS site were transported from the west over the Mediterranean Sea. More than $10 \%$ of the trajectories touched central and western Europe, northern Africa, and the Atlantic. Additionally, more than $5 \%$ of the trajectories showed paths over northern Europe and the northern Atlantic or the African continent. Since many trajectories originated from the Sahara or adjacent regions, mineral dust particles were episodically transported to Cyprus during the campaign. Figure 5 displays the aerosol mass concentration (particulate matter, PM) during the campaign. In desert dust that was transported over thousands of kilometers the particles usually still have a diameter of a few microns (e.g., Prospero, 1999) and thus are larger than most other aerosol species. As these large particles make up the bulk of aerosol mass, PM can be considered as a good proxy for mineral dust in the air. By far the highest concentration of PM occurred on 9 April.

\subsection{Unmanned aircraft systems}

Two different types of UASs were used for INP sampling in this campaign. They are described below.

The Cruiser (Fig. 6) is a fixed-wing, medium-size UAS ( $3.8 \mathrm{~m}$ wingspan) with a two-stroke engine and a maximum takeoff weight of $40 \mathrm{~kg}$ that can carry a payload of up to $10 \mathrm{~kg}$ for a maximum flight duration of $3 \mathrm{~h}$. Since this type of engine may produce a significant source of particle contamination, we thoroughly checked the data of an inte-

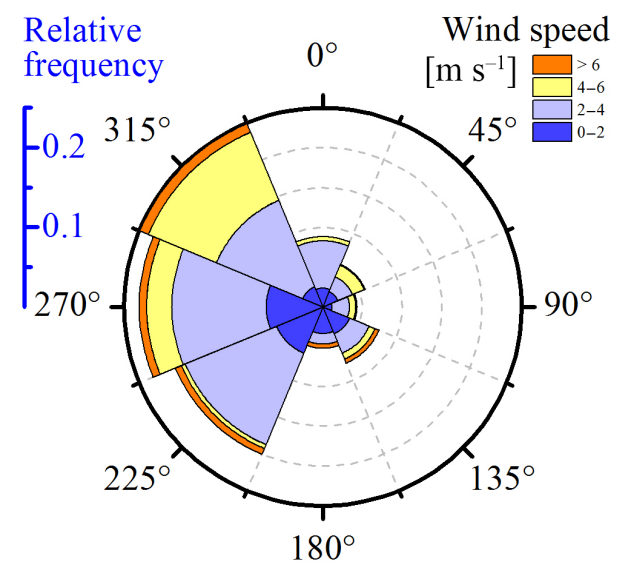

Figure 3. Wind rose based on hourly averages of wind speed and direction measured at CAO by DLI.

Table 1. Thermodynamic conditions of INP analysis in FRIDGE.

\begin{tabular}{lrr}
\hline $\begin{array}{l}T \\
\left({ }^{\circ} \mathrm{C}\right)\end{array}$ & $\begin{array}{r}\mathrm{RH}_{\text {water }} \\
(\%)\end{array}$ & $\begin{array}{r}\mathrm{RH}_{\text {ice }} \\
(\%)\end{array}$ \\
\hline & 95 & 115.6 \\
-20 & 97 & 118.0 \\
& 99 & 120.4 \\
& 101 & 122.9 \\
\hline & 95 & 121.3 \\
-25 & 97 & 123.9 \\
& 99 & 126.4 \\
& 101 & 129.0 \\
\hline & 95 & 127.4 \\
-30 & 97 & 130.1 \\
& 99 & 132.7 \\
& 101 & 135.4 \\
\hline
\end{tabular}

grated aethalometer (AethLabs, Model AE51; Fig. S1 in the Supplement) as well as the data from electron microscopy (cf. Sect. 3.4) for any indications of contamination but did not find any evidence of contaminants in our samples. A small fraction of carbonaceous particles $(<1.5 \%)$ was indeed identified in the samples. However, the same amount was also found in a sample acquired using the batterypowered UAS, suggesting that their origin was not due to the engine's exhaust (Fig. 18, Table 3). During the campaign the maximum altitude never exceeded $2.5 \mathrm{~km}$ above ground level (ca. $2850 \mathrm{~m}$ a.s.l.) due to flight plan restrictions. Flight duration was approximately $1.5 \mathrm{~h}$.

The Skywalker X8 (Fig. 7) has a wingspan of $2.1 \mathrm{~m}$, an electric engine and a maximum takeoff weight of $5 \mathrm{~kg}$. It can fly up to $3 \mathrm{~km}$ altitude with an endurance of about $1 \mathrm{~h}$. The maximum altitude reached in this campaign was $2.5 \mathrm{~km}$ above ground level with a maximum flight duration of about $1 \mathrm{~h}$. Compared to the Cruiser it is a much more flexible system as it does not require a runway for takeoff and landing. 


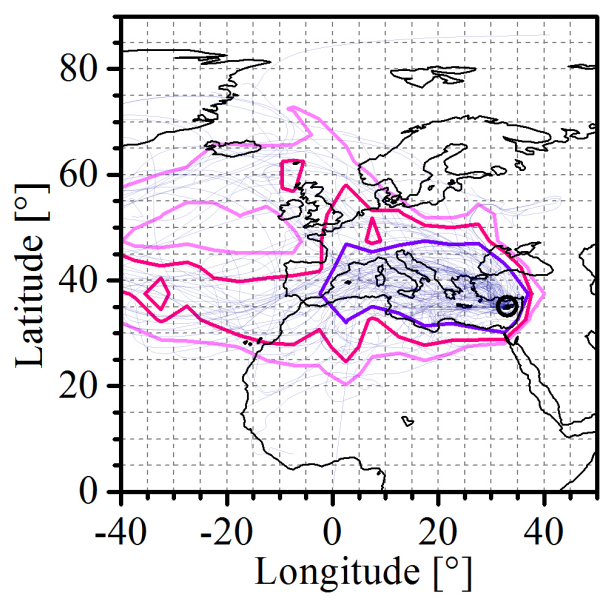

Figure 4. Frequency of trajectories arriving at the UAS airfield (black circle) during the campaign. Back trajectories (10 days) were computed with HYSPLIT (NOAA-ARL, GDAS1, start height 1000 m; Stein et al., 2015; Rolph, 2016). Three back trajectories (faint blue lines) were initiated for each day of the campaign (03:00, 06:00, 09:00 UTC). More than 5\% of the trajectories touch the area that lies inside the light pink lines, more than $10 \%$ that inside the dark pink lines, and more than $20 \%$ that inside the purple line (based on a $5^{\circ}$ by $5^{\circ}$ grid size).

Table 2. Correlation coefficients of INP concentration sampled from UASs $\left(T=-30{ }^{\circ} \mathrm{C} ; \mathrm{RH}_{\text {ice }}=135.4 \%\right)$ to dust-related parameters.

\begin{tabular}{lrrl}
\hline Dust parameter & $R$ & $n$ & Platform/location \\
\hline$n_{a>0.5 \mu \mathrm{m}}$ & 0.97 & 11 & UAS path \\
$\begin{array}{l}\text { Lidar volume } \\
\text { depolarization ratio }\end{array}$ & 0.74 & 46 & $\begin{array}{l}\text { Time and altitude of UAS } \\
\text { path at Nicosia }\end{array}$ \\
$\begin{array}{l}\text { DREAM dust } \\
\text { mass concentration }\end{array}$ & 0.69 & 49 & UAS path \\
PM & 0.59 & 49 & Ground, at CAO \\
AOT & 0.31 & 49 & Total column above CAO \\
\hline
\end{tabular}

Indeed, it can take off from almost anywhere using a bungeelaunching catapult system and it lands on its belly. On the other hand, it is limited to a payload of ca. $2 \mathrm{~kg}$.

The flights were operated from a mobile ground control station, which is equipped with state-of-the-art technology to establish a stable communications link with the UAS for reliable data streaming. The UAS airfield site consists of a private paved runway of $12 \times 200 \mathrm{~m}$ and overhead airspace which is approved by the Civil Aviation Authority of Cyprus. Both UASs run on the same autopilot system, which enables the UASs to fly automatically in a preprogrammed flight plan.

\subsection{Measurements of ice nucleating particles: FRIDGE}

INP concentrations were measured by electrostatic precipitation of aerosol particles onto silicon wafers onboard the UAS,

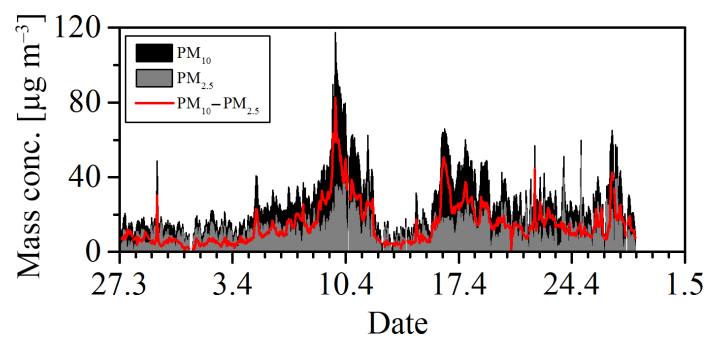

Figure 5. Aerosol mass concentrations $\mathrm{PM}_{10}$ (black), $\mathrm{PM}_{2.5}$ (gray), and the difference between both, i.e., the coarse mode (red) measured at CAO by DLI.

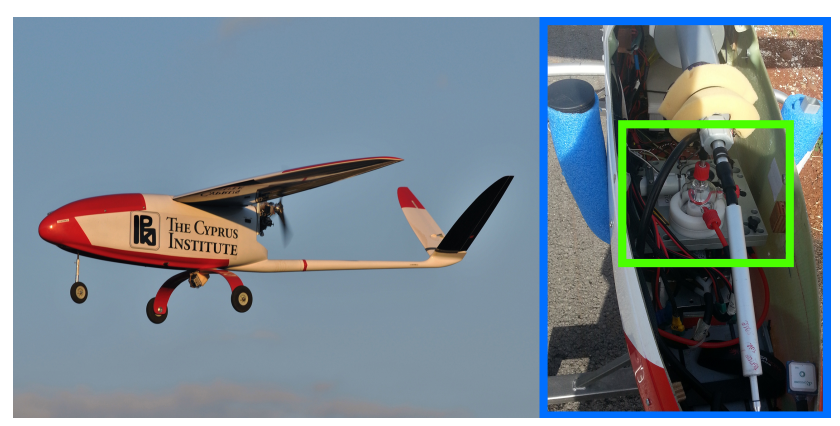

Figure 6. The Cruiser UAS with the multi-sample aerosol collector (green rectangle; photograph by Kjell-Sture Johansen).

followed by laboratory analysis of the samples in the ice nucleus counter FRIDGE. The method for INP measurements was originally introduced in Bundke et al. (2008) and Klein et al. (2010) and was reevaluated by Schrod et al. (2016). FRIDGE usually addresses the deposition or condensation freezing mode(s). FRIDGE's aerosol sampling unit (programmable electrostatic aerosol collector: PEAC; Schrod et al., 2016) either starts and stops sampling automatically in a prescribed time window or can be remotely controlled when connected to a local network or the internet. Sampling procedure, transportation, and storage of wafers are easy to handle without strict precautions, making it a well-suited instrument for the use in a UAS.

Both UASs were equipped with a customized inlet nozzle that was connected by tubing to the aerosol sampling unit. The diameter $D_{\mathrm{s}}$ of the sample inlet nozzle was such that near isokinetic sampling was achieved at the average air speed $U_{0}$ of the UAS and sampling rate $Q$. The error due to anisokinetic sampling was estimated to be typically less than $20 \%$ of particle number for particles up to $10 \mu \mathrm{m}$ in diameter. A detailed discussion of sampling errors due to anisokinetic sampling is presented in the Supplement.

A custom-built, lightweight version $(600 \mathrm{~g})$ of a singlesampling PEAC was integrated into the Skywalker X8 UAS. The Cruiser UAS had a $2.5 \mathrm{~kg}$ multi-sampling PEAC installed, which enabled the sampling of up to seven substrates in one flight. Thereby an altitude profile could be sampled 


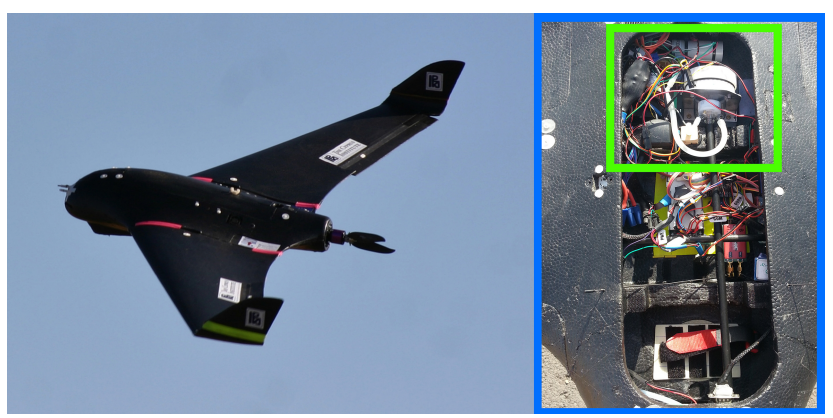

Figure 7. The Skywalker UAS with the single-sample aerosol collector (green rectangle; photograph by Christos Keleshis).

Table 3. Average chemical composition of randomly selected single aerosol particles analyzed by electron microscopy of sample 25 ( 9 April) and sample 39 (21 April).

\begin{tabular}{lrr}
\hline & $\begin{array}{r}\text { Sample 25 } \\
\text { count }\end{array}$ & $\begin{array}{r}\text { Sample 39 } \\
\text { count }\end{array}$ \\
\hline Total particles analyzed & 401 & 628 \\
Saharan dust particles & 395 & 620 \\
Carbonaceous particles & 4 & 8 \\
Other & 2 & 0 \\
\hline Saharan dust particles only & & \\
\hline Aluminosilicates (Mg, K, Fe) & $283(72 \%)$ & $463(75 \%)$ \\
Aluminosilicates (Ti-rich) & $23(6 \%)$ & $21(3 \%)$ \\
Ca-rich aluminosilicates/ & $84(21 \%)$ & $130(21 \%)$ \\
Ca (Mg) carbonates & $5(1 \%)$ & $6(1 \%)$ \\
Gypsum & \multicolumn{2}{c}{} \\
\hline
\end{tabular}

from a single flight. The PEAC uses the principle of electrostatic precipitation to ensure that aerosol particles are homogeneously distributed on the silicon sample substrate. In the sampling process, a pump is used to establish a constant air flow $\left(5 \mathrm{~L} \mathrm{~min}^{-1}\right)$, a high-voltage source generates an electric field and the aerosol particles are charged negatively by collisions with electrons from a corona discharge. The charged aerosol particles then precipitate on the grounded silicon wafer. The sampling process was controlled remotely from the ground control station and was started as soon as the UAS reached the desired altitude and flight conditions were stable. Sampling length was selected according to criteria like the presence of dust, aerosol concentration, and weather conditions and usually ranged between 6 and $20 \mathrm{~min}(30$ to $100 \mathrm{~L}$ of sampled air).

During the campaign a total of 42 flights were performed, which generated a total of 52 samples over 19 different days (Cruiser: 7 flights with a total of 17 samples over 6 days; Skywalker: 35 flights with a total of 35 samples over 16 days).

After the flights the samples were analyzed in the isostatic diffusion chamber FRIDGE. A sample substrate is placed on the cold table inside the sample cell. The evacu- ated cell is then inflated with water vapor. The combination of desired substrate temperature and ice supersaturation defines the exact pressure of water vapor that is inserted into the measurement cell. The water vapor rapidly activates the INPs, and ice crystals begin to grow on the surface of these aerosol particles. A CCD (charge-coupled device) camera (AVT Stingray F-504C 2/3") monitors the growth of ice (usually for $100 \mathrm{~s}$ ) and a LabView-controlled software automatically detects changes in the brightness of the images of the emerging ice crystals. For this purpose the real-time picture is compared to a reference picture taken prior to the measurement. After a measurement is completed the sample cell is evacuated again and the ice crystals evaporate completely. Then the temperature and relative humidity can be set to new conditions for the next activation.

During this campaign, samples were usually analyzed at $-20,-25$, and $-30^{\circ} \mathrm{C}$ and relative humidity of $95,97,99$, and $101 \%$ with respect to water or equivalently 115 to $135 \%$ with respect to ice (see Table 1).

After the analysis, selected samples were examined by scanning electron microscopy (SEM) to gain information on the chemical composition and morphology.

For a detailed description of the sampling procedure and FRIDGE's measurement principle as well as its limitations and possible caveats, see Schrod et al. (2016). These limitations include, for example, (a) the possible loss of volatile aerosol constituents due to the analysis under medium vacuum, (b) the possibility of a transient depletion of water vapor above the nucleating particles due to the uptake of water occurring at very high numbers of particles on the substrate, and (c) technical restrictions regarding the method's time resolution. Although our measurements can cover the freezing induced by nuclei that are immersed in droplets after condensation (i.e., condensation freezing), they do not involve the freezing of macroscopic droplets with immersed INPs.

\subsection{Electron microscopy}

Size and elemental composition of individual particles of selected samples were investigated by scanning electron microscopy using a field emission gun instrument (FEI ESEM Quanta 200 FEG, Eindhoven, the Netherlands), equipped with an energy-dispersive X-ray microanalysis system (EDX). Almost all ambient particle types are detectable by SEM-EDX analysis, but as SEM is a highvacuum method, very volatile organic compounds (VVOCs) will be lost. The samples were analyzed automatically by the software-controlled electron microscope (software EDAX/AMETEK GENESIS 5.231). Since the substrates cause a high silicon signal, silicon could not be used for the classification of desert dust particles. Instead, aluminum was used for the identification of the Saharan components (in addition with: $\mathrm{Mg}, \mathrm{K}, \mathrm{Ca}, \mathrm{Ti}$, and $\mathrm{Fe}$ ). Besides the main aluminosilicate group, Ti-rich aluminosilicates and $\mathrm{Ca}$-rich parti- 


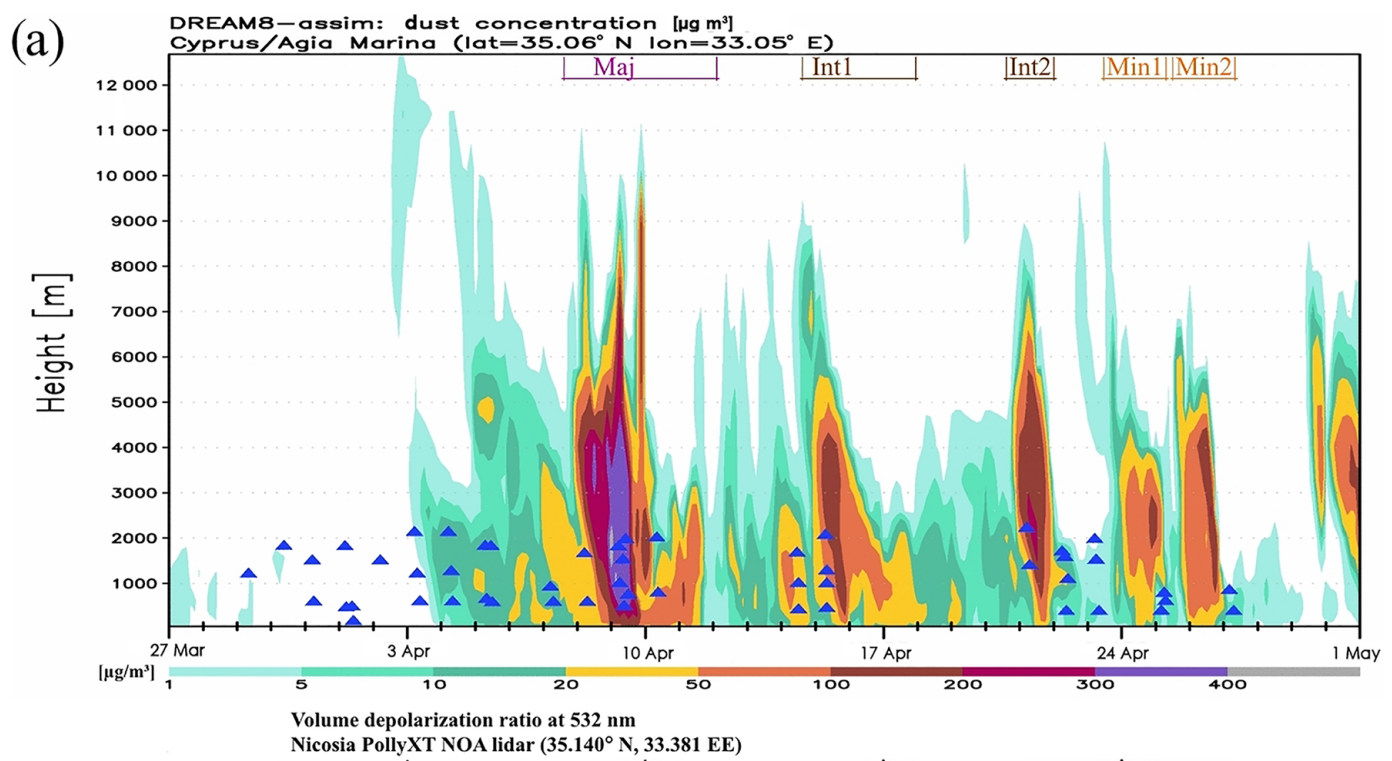

(b)

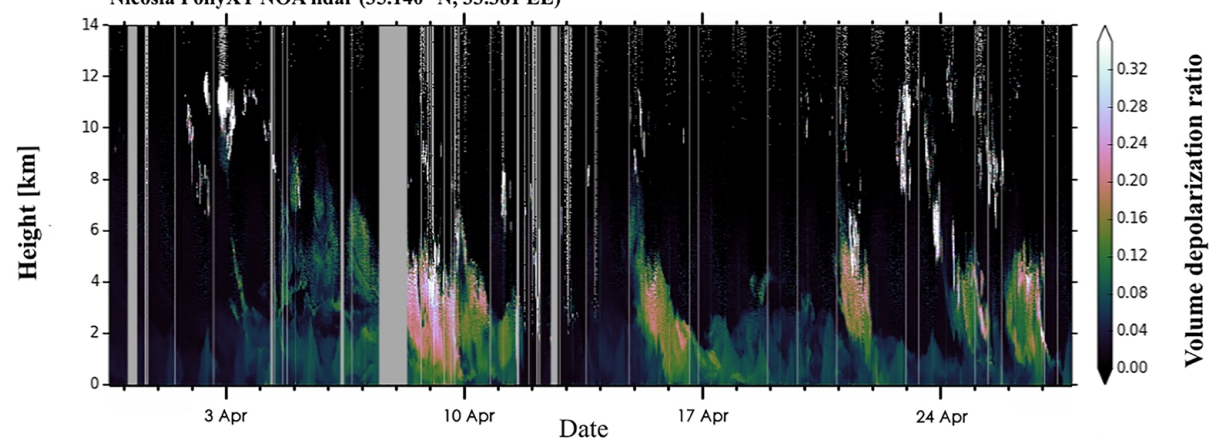

Figure 8. (a) Time series of dust mass concentration vs. altitude predicted by DREAM for the UAS airfield site. Episodes of mineral dust are categorized as major (MajDE), intermediate ( $\mathrm{Int}_{\mathrm{DE} 1}$, $\left.\mathrm{Int}_{\mathrm{DE} 2}\right)$, or minor (Min $\mathrm{DE}_{\mathrm{D}}$, Min $\mathrm{DE}_{\mathrm{D} 2}$ ) dust events; see text. Blue triangles indicate UAS flights with INP sampling. (b) Time series of volume depolarization ratio at $532 \mathrm{~nm}$ vs. height obtained from PollyXT lidar in Nicosia.

cles (either $\mathrm{Ca}(\mathrm{Mg})$ carbonates or mixtures of $\mathrm{Ca}$ carbonates with aluminosilicates) were classified separately.

\subsection{Measurements of aerosol number concentrations: Met One OPC}

The Cruiser UAS was equipped with an optical particle counter (OPC; Met One Instruments, Model 212 Profiler) that measured the size distribution of airborne aerosol as a function of its optical diameter. The OPC reports aerosol particle number concentration with $1 \mathrm{~Hz}$ resolution in eight different channels ranging from 0.3 to $10 \mu \mathrm{m}$. The inlet of the OPC was preheated to keep relative humidity below $50 \%$ to minimize the influence of water absorption onto particles.

\subsection{Lidar}

An automated multiwavelength PollyXT Raman polarization lidar with near-range capabilities (Althausen et al., 2009; Engelmann et al., 2016) was operated at Nicosia. This system emits linearly polarized light at 355,532 , and
$1064 \mathrm{~nm}$ and has 10 receiver channels. The system is part of PollyNET (Baars et al., 2016) and measured around-theclock autonomously. EARLINET quality standards were applied; e.g., the depolarization signal was calibrated automatically three times a day. The vertical and temporal resolution are $7.5 \mathrm{~m}$ and $30 \mathrm{~s}$, respectively. More details can be found in Engelmann et al. (2016).

Products from the lidar used in this study are time-height plots of the attenuated backscatter coefficient at $1064 \mathrm{~nm}$ and the volume depolarization ratio at $532 \mathrm{~nm}$. All heights are above ground level. The attenuated backscatter coefficient is the calibrated range-corrected lidar signal (see, e.g., Wandinger, 2012); i.e., it contains information on the backscattering by molecules and particles and is attenuated by the extinction of these two types of scatterers. However, at $1064 \mathrm{~nm}$, molecular scattering and total extinction are very low, so that the attenuated backscatter coefficient at $1064 \mathrm{~nm}$ is nearly equal to the real particle backscatter coefficient. Thus, this product gives an indication of the amount of particles in the atmosphere. The lidar signal is calibrated using $2 \mathrm{~h}$ mean profiles of extinction and backscatter coefficients 
obtained with the Raman method (Ansmann et al., 1992). The volume depolarization ratio is defined as the ratio of the backscattered light in orthogonal and parallel polarization plane with respect to the plane of polarization of the emitted light. It contains information from the whole volume, i.e., molecules and particles. It is a measure of the nonsphericity of the observed scatterers; i.e., the higher the value the more non-spherical particles (e.g., dust) are present. At $532 \mathrm{~nm}$ Saharan dust typically yields a particle depolarization ratio of about 0.3 , whereas spherical scatterers are considered to show a particle depolarization ratio of less than 0.05 (Mamouri and Ansmann, 2014, and references therein). Depolarization from molecular scattering is between 0.005 and 0.006 .

Using the particle backscatter coefficient and the particle depolarization ratio at $532 \mathrm{~nm}$, the number concentration of particles with a diameter $>0.5 \mu \mathrm{m}$ can be estimated with an uncertainty of $\pm 30 \%$ from lidar observations following the methodology of Mamouri and Ansmann (2016). A dust lidar ratio of $40 \mathrm{sr}$ and an extinction-to-number conversion factor of 0.2 have been considered for that methodology according to the values provided by Mamouri and Ansmann (2016).

\subsection{Dust transport model DREAM}

In this study we used DREAM (Nickovic et al., 2001; Nickovic, 2005; Pejanovic et al., 2011) driven by the National Centers for Environmental Predictions Nonhydrostatic Multiscale atmospheric Model - NMME (Janjic et al., 2001; Janjic, 2003; Janjic et al., 2011). The NMME-DREAM coupled modeling system has been developed to predict the atmospheric dust process, including dust emission from desert surfaces, horizontal and vertical turbulent mixing, long-range transport, and deposition. It solves the Euler-type partial differential nonlinear equation for dust mass continuity. Dust concentration is composed of eight bins with radii ranging from 0.15 to $7.1 \mu \mathrm{m}$. Dust emission in the model is proportional to the intensity of the turbulent vertical mixing regimes (laminar, transient, and turbulent mixing) near the surface. The specification of dust sources is based on the mapping of the areas that are dust-productive under favorable weather conditions. The USGS land cover data combined with the preferential sources of dust originating from the sediments in paleo-lake and riverine beds (Ginoux et al., 2001) have been used to define barren and arid soils as dust-productive areas. The North Africa-Middle East-Europe domain of the model has a horizontal resolution of $25 \mathrm{~km}$; in the vertical, the model has 28 layers ranging from the surface to $100 \mathrm{hPa}$. The initial and boundary atmospheric conditions for NMME were updated every $24 \mathrm{~h}$ using the ECMWF $0.5^{\circ}$ analysis data. The concentration was set to zero at the "cold start" of DREAM, launched 4 days before 1 April, thus permitting a 4-day spin-up time to develop a meaningful concentration field at the date considered as an effective model start. After that time, 24-hour dust concentration forecasts from the

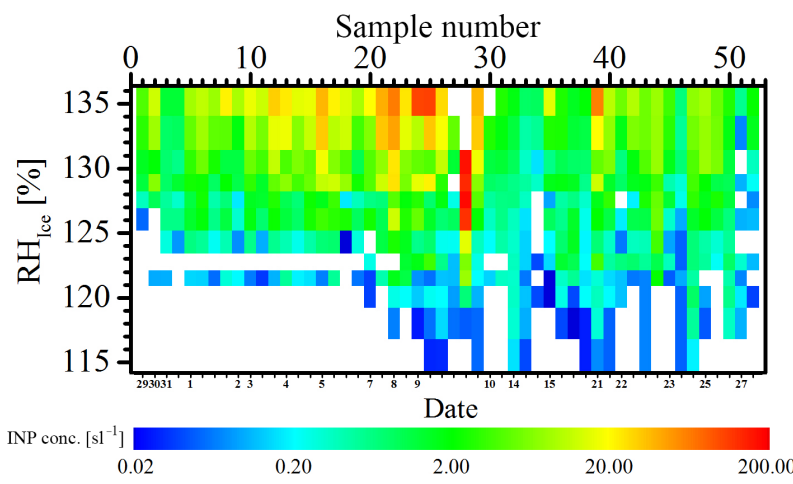

Figure 9. INP concentrations (color-coded) as function of relative humidity with respect to ice in the temperature range from -20 to $-30^{\circ} \mathrm{C}$ (see Table 1) observed during all UAS flights. The date (in days of March (29 to 31) and April (1 to 27)) corresponding to the sample number is given on the lower abscissa. Where no number appears, the date is the same as for the previous sample(s).

previous-day runs have been declared as initial states for the next-day run of DREAM.

\section{Results and discussion}

\subsection{Mineral dust particles}

During the entire month of the campaign, desert dust was frequently mobilized mainly from sources in the central and western Sahara and was injected into the prevailing westerly flow, which carried it eastward across the Mediterranean Sea. Some of the dust plumes were carried as far north as central and eastern Europe, but in general the filaments meandered eastward over the Mediterranean Sea and partly over Cyprus. In the atmosphere above Cyprus, we encountered one major dust event (MajDE, 8 to 11 April), two intermediate dust events (Int ${ }_{\mathrm{DE} 1}, 15$ to 16 April, and Int $\mathrm{DE}_{2}, 21$ April) and two minor dust events (Min ${ }_{\mathrm{DE} 1}, 24$ April, and Min 26 April; Fig. 8). The classification of these different dust events builds on the peak dust concentrations in the operational layer of the UASs ( 0 to $3 \mathrm{~km}$ altitude) as predicted by DREAM: a dust event was classified as (a) major, when the model dust mass concentrations for more than $12 \mathrm{~h}$ continuously exceeded $200 \mathrm{\mu g} \mathrm{m}^{-3}$, (b) intermediate between 100 and $200 \mu \mathrm{g} \mathrm{m}^{-3}$, and (c) minor between 50 and $100 \mu \mathrm{g} \mathrm{m}^{-3}$. The corresponding time series of the predicted dust mass concentration is shown in Fig. 8a. Figure 8 b shows lidar observations of the volume linear depolarization ratio at $532 \mathrm{~nm}$ for the same period. The agreement between the model and the observations is very good: a high dust concentration correlates to a high-volume depolarization ratio $(R=0.75$ for $n=10850$ pairs of $3 \mathrm{~h}$ and $100 \mathrm{~m}$ interpolated data in the altitude range of 0 to $5 \mathrm{~km}$ a.g.1.).

The evolution of the dust load over the Mediterranean Basin and its adjacent regions during the course of the cam- 
paign as predicted by DREAM is shown in the Supplement (available online). The Movie S1 depicts the dust load, i.e., the vertically integrated mass of mineral dust per surface area, over the stated regions (left panel). The movie starts on 28 March and ends on 1 May 2016. The time step is $3 \mathrm{~h}$. The dust load ranges from 0.1 to $4 \mathrm{~g} \mathrm{~m}^{-2}$, indicated by colors from green to orange to purple. Blue contours show the $700 \mathrm{hPa}$ geopotential height. The middle panel of the movie zooms in on Cyprus and its surrounding area. Here, the wind field at $3 \mathrm{~km}$ is indicated by arrows. The right panel displays the vertical distribution of dust above the UAS airfield site, using the same time step.

In the first days of the campaign (27 March to 7 April) no significant dust was observed throughout the lowest $10 \mathrm{~km}$ of the atmosphere over Cyprus. On 2 and 3 April, a very strong dust outbreak from sources in the western Sahara carried dust far north across Europe but did not affect the Eastern Mediterranean. On 7 April dust was mobilized from central Saharan sources (ranging diagonally from northern Niger at $20^{\circ} \mathrm{N}, 10^{\circ} \mathrm{E}$ to northeastern Libya at $31^{\circ} \mathrm{N}, 23^{\circ} \mathrm{E}$; dark brown ellipse in Fig 1b) and was advected by southwesterly flow directly towards Cyprus, causing the major dust event of the campaign on 8 and 9 April. This plume impacted Cyprus with a layer of dust arriving at 3 to $4 \mathrm{~km}$ altitude above the ground early on 8 April. The concentration intensified until it peaked at $450 \mu \mathrm{g} \mathrm{m}^{-3}$ at 2 to $3 \mathrm{~km}$ altitude in the night of 8 to 9 April. The highest dust load reached Cyprus at 06:00 UTC on 9 April, when a homogeneous dust layer of $350 \mu \mathrm{g} \mathrm{m}^{-3}$ between 1 and $6 \mathrm{~km}$ altitude swept across the island. Until 12:00 UTC DREAM dust concentrations still remained at the same high levels for a broad range of altitudes (1-4 km). Thereafter the concentration decreased steadily towards clean conditions, which prevailed after 11 April. The next dust episode of intermediate strength was observed on 15 and 16 April with a peak of $150 \mu \mathrm{g} \mathrm{m}^{-3}$ at about $2-4 \mathrm{~km}$ above ground level. For this case DREAM suggests source regions of the mineral dust in western and central North Africa (orange rectangle in Fig 1b). After this dust layer passed over Cyprus, concentrations decreased while the dust sedimented on 17 April. At about this date dust was mobilized in central North Africa once more (yellow rectangle in Fig 1b). The corresponding intermediate dust event reached Cyprus on 21 April and showed peak concentrations above $150 \mu \mathrm{g} \mathrm{m}^{-3}$ at 2 to $5 \mathrm{~km}$ altitude. In the last days of the campaign, two minor dust plumes ( 24 and 26 April) traveled to Cyprus, both coming from sources in northeastern Libya (light brown rectangle in Fig 1b).

\subsection{Ice nucleating particles}

The concentrations of INPs measured from the UAS range over 5 orders of magnitude when the full range of analyzing conditions is considered. Figure 9 shows the INP concentrations (color-coded) as a function of relative humidity with respect to ice $\left(\mathrm{RH}_{\text {ice }}\right)$. At the lowest ice supersatura-

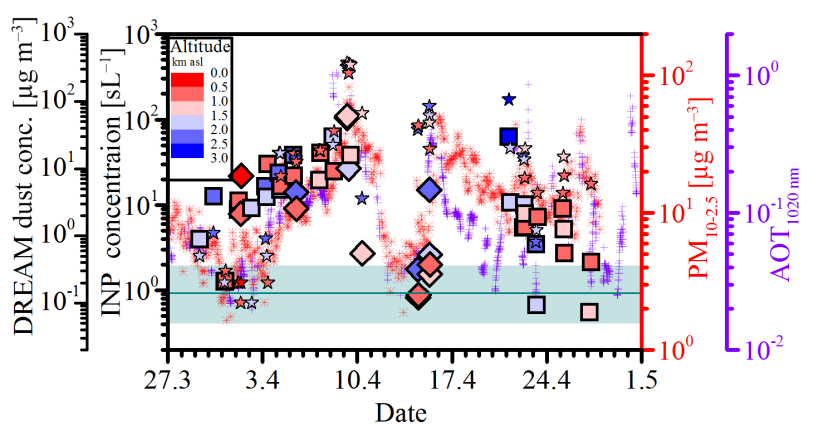

Figure 10. INP concentration $\left(T=-30{ }^{\circ} \mathrm{C} ; \mathrm{RH}_{\text {ice }}=135.4 \%\right)$ sampled during flights with Skywalker (squares) and Cruiser (diamonds). The symbols are color-coded by the mean sampling altitude. The cyan line gives the median INP concentration of 33 FRIDGE measurements from this campaign at ground level at CAO (532 $\mathrm{m}$ a.s.1.); the shaded area shows the interquartile range. The stars represent DREAM output of the dust mass concentration. The dust proxies PM and AOT (P. Goloumb, personal communication, 2016) are indicated in red and purple.

tions and highest temperature tested (i.e., at $-20^{\circ} \mathrm{C}$ ), concentrations were typically around $0.1 \mathrm{std} \mathrm{L}^{-1}$ or below. Concentrations increased exponentially with ice supersaturation. At the highest relative humidity and lowest temperature (i.e., at $-30^{\circ} \mathrm{C}$ ) more than $100 \mathrm{INPs}$ std $\mathrm{L}^{-1}$ were measured. Note that in sample 28, INPs could not be analyzed quantitatively at the highest supersaturation and lowest temperature due to overloading, causing problems in the algorithm that distinguished and counted individual crystals. Samples 1 to 19 , 21,30 , and 31 were only analyzed at -25 and $-30^{\circ} \mathrm{C}$. The INP concentrations increased from the beginning of the campaign until they reached a pronounced maximum on 9 April (MajDE), followed by a minimum right after. In the following days, INP concentrations were generally lower than in the first half of the campaign except for single events (e.g., 21 April, Int DE2). No flights could be performed between 11 and 13 and between 16 and 20 April due to unfavorable meteorological conditions and maintenance on the UASs.

The contribution of dust to local INPs is reflected by the good agreement between INPs and specific dust parameters, such as PM, aerosol optical thickness (AOT), and the modeled dust mass concentration. Figure 10 presents the INP concentration at $T=-30{ }^{\circ} \mathrm{C}$ and $\mathrm{RH}_{\text {ice }}=135.4 \%$ (i.e., the top row of Fig. 9) from UASs together with coarse-mode PM $\left(\mathrm{PM}_{10}-\mathrm{PM}_{2.5}\right)$, AOT at $1020 \mathrm{~nm}$ measured at $\mathrm{CAO}$, and the dust mass concentrations calculated by DREAM for the sampling altitude. The mean UAS sampling altitude is given by the color-coding of the symbols.

The mean vertical INP profile as derived from averaging INP concentrations in the height bins 0.5 to 1,1 to $1.5,1.5$ to 2 , and 2 to $2.5 \mathrm{~km}$ is given in Fig. 11. The INP data in each altitude bin show considerable spread. However, the median vertical profile shows the lowest INP concentration close to the surface and a gradual increase towards the top layer. 
The low INP concentration of around $1 \mathrm{~L}^{-1}$ measured from FRIDGE samples at ground level at CAO is consistent with the observations made by the UASs. This reflects the overall situation during the campaign, in which layers of dust were frequently advected over the island at 2 to $3 \mathrm{~km}$ altitude (e.g., Fig. S4). The lower parts of these layers were sampled by the UASs. The vertical profiles of dust calculated by DREAM (right panel of Movie S1) support this view. The dominance of large-scale dust advection can be seen from the correlation between the levels of INPs aloft and at the ground (Table 2). The highest correlation is found between INPs and the total particle number concentration with diameters larger than $0.5 \mu \mathrm{m}\left(n_{a>0.5}\right)$, both measured onboard the UAS $(R=0.97$; $n=11)$. The volume depolarization ratio at the time and altitude of the INP sampling is also well correlated $(R=0.74$; $n=46$ ). The correlation between the individual local concentrations of INPs sampled from UASs and of the aerosol mass concentration calculated for the same sampling path by DREAM is $R=0.69 ; n=49$. INPs from the UAS are correlated to coarse-mode PM $(R=0.59 ; n=49)$ measured at $\mathrm{CAO}$ at ground level and to the vertically integrated AOT $(R=0.31 ; n=49)$. Furthermore, the peaks of INPs and the mineral dust parameters coincide (Fig. 10).

\subsubsection{Parameterizations}

The establishment of robust empirical correlations between ice nucleating properties and physical characteristics (size spectra) of atmospheric aerosol has been a challenge for decades (Georgii and Kleinjung, 1976), since it might allow us to predict INPs from aerosol data, which are much more easily available than INP measurements. As presented above, we found that the INP concentration from UASs is highly correlated to the number of large particles measured simultaneously by OPC onboard. Thus, in the following we will compare our INP measurements to recent particle-based empirical parameterizations of INPs $\left(n_{\mathrm{INP}}\left(T_{\mathrm{k}}\right)\right)$. However, we have to bear in mind that the nucleation modes addressed by the different methods on which these parameterizations build do not perfectly overlap. From aircraft measurements in various different locations, DeMott et al. (2010) derived the following relationship (hereafter called D10):

$n_{\mathrm{INP}, \mathrm{D} 10}\left(T_{\mathrm{k}}\right)=a\left(273.16-T_{\mathrm{k}}\right)^{b}\left(n_{a>0.5}\right)^{\left(c\left(273.16-T_{\mathrm{k}}\right)+d\right)}$,

where the empirical parameters were set to $a=0.0000594$, $b=3.33, c=0.0264$, and $d=0.0033$. Equation (1) was revised by DeMott et al. (2015) for mineral dust scenarios; i.e., the new parameterization (hereafter called D15) was obtained by compiling data from mineral dust INPs collected in the laboratory and from aircraft-based CFDC measurements inside mineral dust layers. D15 has been developed from the parameterizations of DeMott et al. (2010) and Tobo

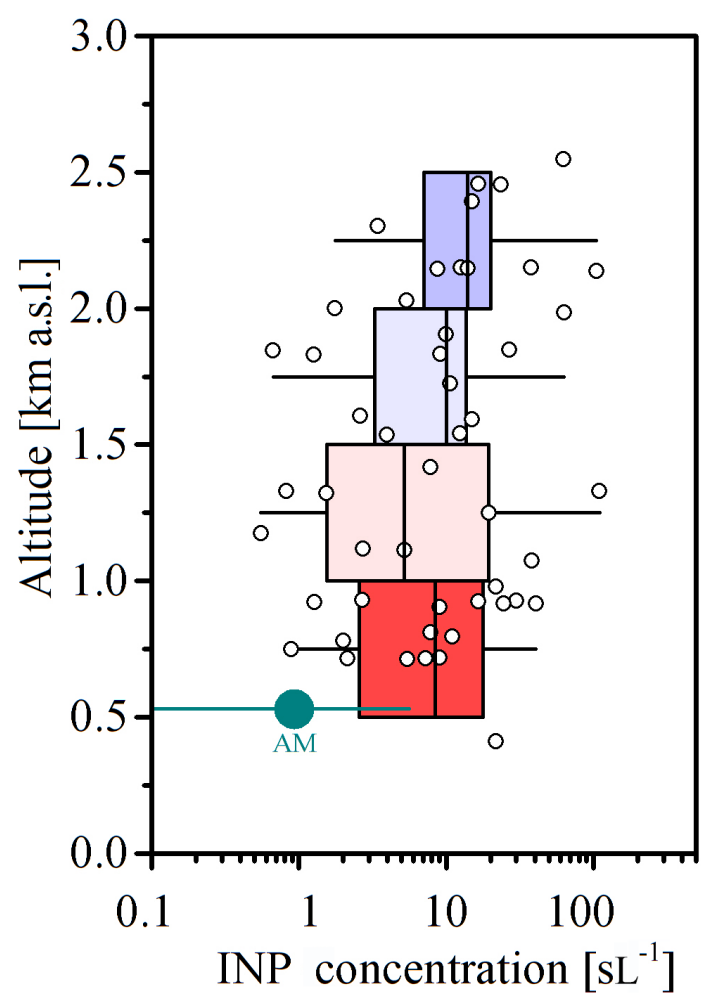

Figure 11. INP concentrations $\left(T=-30^{\circ} \mathrm{C}\right.$; $\mathrm{RH}_{\text {ice }}=135.4 \%$, circles) versus sampling altitude. The boxes (colors same as Fig. 10) show the interquartile range of the data with the median given as a vertical solid line, the black bars give the full range of concentrations. The median INP concentration of 33 FRIDGE measurements from this campaign at CAO in Agia Marina (AM; $532 \mathrm{~m}$ a.s.l.) is indicated by a the cyan circle; the range is shown by a cyan bar.

et al. (2013) and is given by Eq. (2):

$$
\begin{gathered}
n_{\mathrm{INP}, \mathrm{D} 15}\left(T_{\mathrm{k}}\right)=(\mathrm{cf})\left(n_{a>0.5}\right)^{\left(\alpha\left(273.16-T_{\mathrm{k}}\right)+\beta\right)} \\
\exp \left(\gamma\left(273.16-T_{\mathrm{k}}\right)+\delta\right) .
\end{gathered}
$$

The parameters $\alpha=0, \beta=1.25, \gamma=0.46$, and $\delta=-11.6$ were empirically fitted by DeMott et al. (2015). The calibration factor cf has no deeper underlying physical meaning. DeMott et al. (2015) state that the constants $\alpha, \beta, \gamma$, and $\delta$ could have captured this coefficient, but they wanted to introduce it separately to account for instrument-specific calibration of their CFDC. More precisely, when measuring mineral dust aerosol in the AIDA cloud expansion chamber at $\mathrm{RH}_{\text {water }}=105 \%$, they found INP concentrations lower by a factor of 3 than the maximum concentration shortly before droplet breakthrough is observed in the CFDC (usually at $\mathrm{RH}_{\mathrm{water}}=108$ to $109 \%$ ). Therefore, they argue that a prefactor of $\mathrm{cf}=3$ is needed to obtain the maximum immersion freezing INP concentration for mineral-dust-specific atmospheric data.

In this paper the calibration factor $\mathrm{cf}$ is handled completely independently of this definition. Instead, we use it simply as 
a mathematical degree of freedom when fitting the observed measurements to the predicted INP concentrations.

Figure 12 compares the INP concentration that we measured over Cyprus (for $\mathrm{RH}_{\mathrm{water}}=101 \% ; T_{\mathrm{k}}=253,248$, and $243 \mathrm{~K}$ ) to the INP concentration that is predicted for the same temperature (but somewhat higher $\mathrm{RH}$ ) on the basis of the D10 and D15 parameterizations and the $n_{a>0.5}$ that was measured onboard the UAS. D10 is shown in Fig. 12a and D15 in Fig. 12b. The range of confidence intervals shown in red $(1 \sigma)$ and gray $(2 \sigma)$ is a little smaller for D10 than for D15. D10 predicts the high concentrations better than D15, but the lower concentrations are predicted poorly. The dust-specific parameterization D15 on the other hand seems to be better suited to predict the observed measurements. While the slope of Fig. 12b is close to unity, the measurements are 1 order of magnitude lower than the estimate based on the parameterization. At this stage it remains difficult to determine whether this offset is caused by differences in (a) instrumentation and measurement technique in general, (b) the lacking overlap of freezing modes between the different experimental methods, (c) different aerosol inlet systems (D15 used 1.5 to $2.4 \mu \mathrm{m}$ cutoffs, whereas we used no cutoff), (d) a variation in relative humidity (D15: 105\%; FRIDGE: $101 \%$ ), or a combination of all these. Furthermore, not all of our samples may have been affected by dust. In a dust case study over Germany (Schrod et al., 2016), we recently observed a slope close to unity between FRIDGE and D15, but with a $40 \%$ underestimate $\left(T_{\mathrm{k}}=257\right.$ to $\left.249 \mathrm{~K}\right)$ of the INPs observed by FRIDGE as compared to the D15 parameterization.

However, in the case presented here, we do see a better fit between observed FRIDGE INP concentrations and D15 predicted immersion mode INP concentration when empirically setting $\mathrm{cf}=0.086$ (Fig. 12c), thus lowering the predicted values by a factor of 11 . With this alteration the confidence intervals are narrowed markedly. Now $70 \%$ of the data are within a factor of 3.28 and $97 \%$ are within a factor of 14.37 around the $1: 1$ line. Even when allowing all the parameters to change freely, we only achieve a slightly better agreement (Fig. 12d). In this case the parameter $\gamma$ was set to $\gamma=0.472$, while the $\mathrm{cf}=0.086$ and the other parameters were kept fixed. Then $70 \%$ of the data are located within a factor of 2.63 , and $97 \%$ within a factor of 10.65 around the $1: 1$ line. Note that the variation of these constants (other than the pre-factor cf) between this best-fit case and the values given in D15 is very small.

\subsubsection{Ice active fraction and active site density}

The nucleating properties of the aerosol encountered over Cyprus may be characterized by its activated fraction (AF) as well as by the active site density $\left(n_{\mathrm{s}}\right)$. Both parameters are a measure of how well the aerosol acted as a seed surface for ice nucleation. AF stands for the fraction of INPs out of the total aerosol particle number (Eq. 3); i.e., it indicates how many particles are needed in total to encounter one active ice
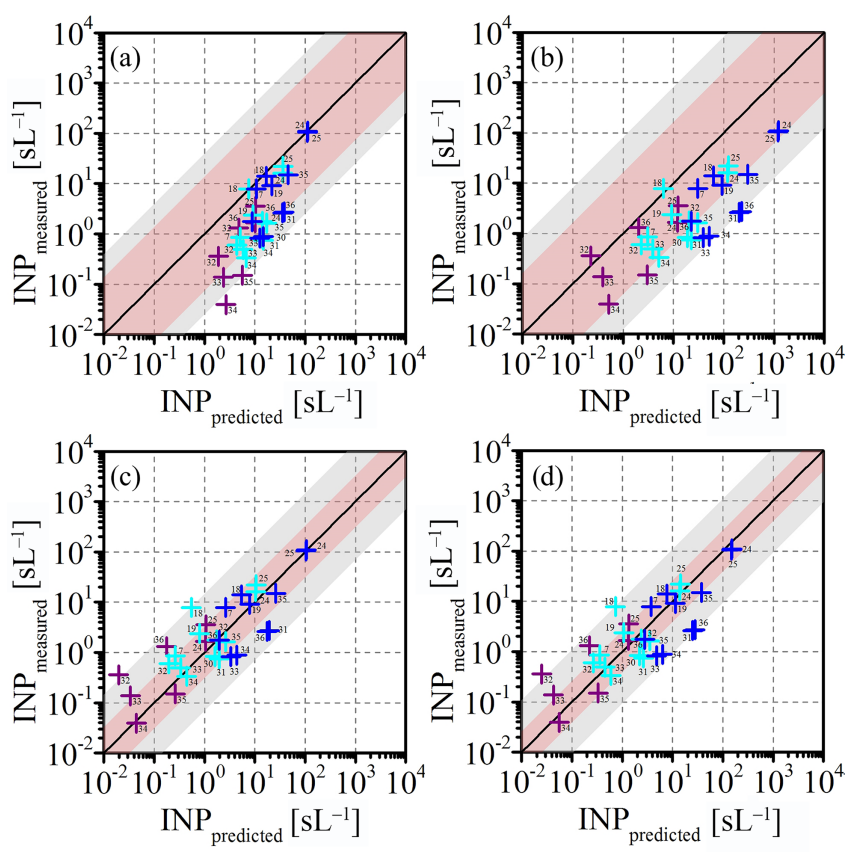

Figure 12. Scatterplot of INP concentration measured by FRIDGE against the same as predicted by (a) D10 and (b) D15. Panel (c) uses the same parameterization as (b) with the exception that $\mathrm{cf}$ is set to the best fit of 0.086. Panel (d) also has the same fixed values for $\alpha, \beta, \delta$, and cf as in (c), but the constant $\gamma$ is fitted to best represent the measured data. The confidence intervals of $1 \sigma(70 \%)$ and $2 \sigma(97 \%)$ are indicated by a red and gray belt around the $1: 1$ line. FRIDGE data were measured at $\mathrm{RH}_{\mathrm{water}}=101 \%$ and temperatures $-20^{\circ} \mathrm{C}$ (purple), $-25^{\circ} \mathrm{C}$ (cyan), and $-30{ }^{\circ} \mathrm{C}$ (blue) and had valid OPC measurements carried out simultaneously aboard Cruiser. Numbers beside the symbols corresponds to the sample numbers from Fig. 9.

nucleus:

$\mathrm{AF}=\frac{n_{\mathrm{INP}}}{\left(n_{a>0.5}\right)}$

The $n_{\mathrm{s}}$ parameter is an estimate of how many active sites are present upon the total aerosol surface $\left(s_{a>0.5}\right.$; Eq. 4$)$ :

$n_{\mathrm{s}} \approx \frac{n_{\mathrm{INP}}}{s_{a>0.5}}$.

Figure 13 depicts AF (a) and $n_{\mathrm{S}}$ (b) as functions of $\mathrm{RH}_{\text {ice }}$ in a box plot. Both parameters increase towards higher $\mathrm{RH}_{\text {ice }}$ in a similar manner because they originate from the same aerosol and INP values. An exponential increase with $\mathrm{RH}_{\text {ice }}$ is discerned, which is characteristic of deposition freezing (Meyers et al., 1992). Some measurements are made nearly at the same supersaturation but at different temperatures (see the set of freezing conditions in Table 1). This yields an interesting result that is somewhat difficult to interpret. It appears that in a sample that is analyzed at roughly the same $\mathrm{RH}_{\text {ice }}$ but at a different temperature, the higher INP counts are found at the higher temperature, which is the opposite 

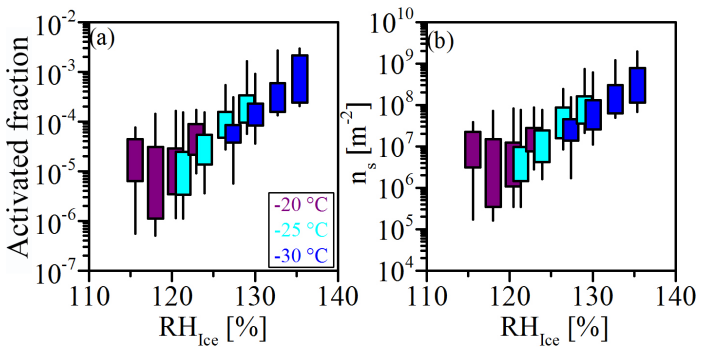

Figure 13. Activated fraction (AF) (a) and active site density $n_{\mathrm{S}}$ (b) of aerosol particles larger than $0.5 \mu \mathrm{m}$ in diameter as a function of ice supersaturation for Cruiser flights. The boxes represent the interquartile range. Vertical lines give the full range of observations. The width of the boxes represents the uncertainty in humidity $( \pm 1 \%)$.

of what is expected. Since the number of measurements are relatively small, we cannot say with certainty whether this observation is a real effect or not. Possibly, the higher values at higher temperatures could be explained by condensation freezing starting to matter at RH close to water saturation, whereas at the lower temperatures only the deposition mode dominates the freezing process.

The values of $\mathrm{AF}$ and $n_{\mathrm{s}}$ compare reasonably well with measurements performed in atmospheric environments influenced by mineral dust. For example, Boose et al. (2016) found that the active site density from 2-month measurement data at Izaña in Tenerife ranged between $7 \times 10^{7}-3 \times 10^{8} \mathrm{~m}^{-2}$ at $T=-25^{\circ} \mathrm{C}, \mathrm{RH}_{\text {ice }}=130 \%$ (this study: $2 \times 10^{7}-7 \times 10^{8} \mathrm{~m}^{-2}$ at $T=-25^{\circ} \mathrm{C}, \mathrm{RH}_{\text {ice }}=129 \%$; Fig. S5a) and between $2 \times 10^{8}-2 \times 10^{9} \mathrm{~m}^{-2}$ at $T=-33^{\circ} \mathrm{C}$, $\mathrm{RH}_{\text {ice }}=135 \% \quad$ (this study: $7 \times 10^{7}-2 \times 10^{9} \mathrm{~m}^{-2}$ at $T=-30{ }^{\circ} \mathrm{C}, \mathrm{RH}_{\mathrm{ice}}=135 \%$; Fig. S5b). Figure $\mathrm{S} 5$ also compares the observed active site densities with the laboratory-based mineral dust immersion freezing parameterizations of Niemand et al. (2012) (hereafter: N12) and Atkinson et al. (2013) (hereafter: A13). Both parameterizations predict higher active site densities than were found in this study. The data agree to an acceptable level with N12, with the highest measured $n_{\mathrm{s}}$ being usually within the same order of magnitude as N12 or better. However, the K feldspar parameterization A13 does not match the observed slope. Especially for cold temperatures the data diverge from A13 by several orders of magnitude. As probably only a fraction of dust particles was composed of this highly ice-active material, we did not expect a good agreement.

Furthermore, we did not find a significant variation of AF and $n_{\mathrm{s}}$ during the campaign (not shown), indicating that the composition of the aerosol and its source might not have changed substantially between the different UAS flights. This suggests that a background of mineral dust of fairly uniform nucleating properties was present over the Mediterranean Sea at all times, and it was only the burden of dust that affected the INP concentration that we measured.
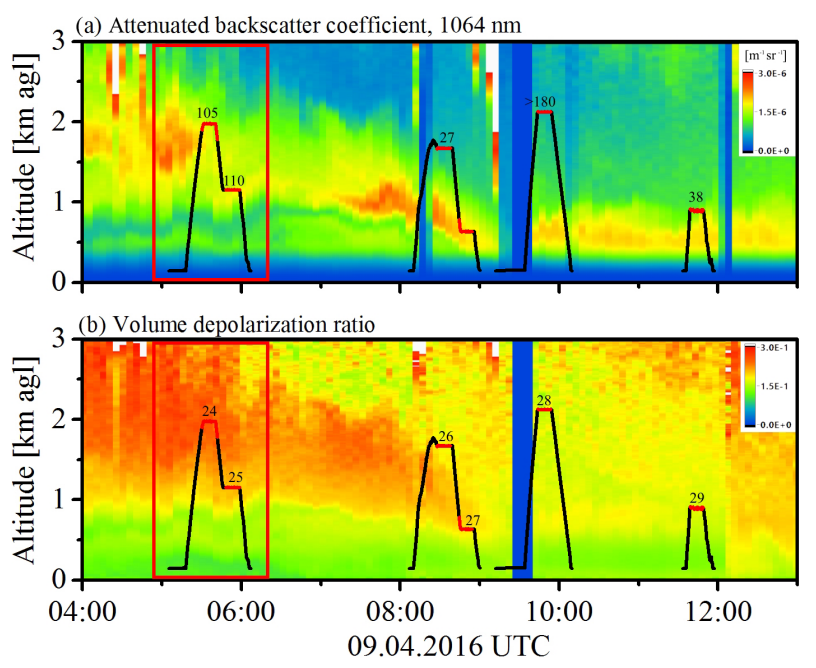

Figure 14. Time series of lidar observations measured in Nicosia on 9 April. The upper panel shows the attenuated backscatter signal at $1064 \mathrm{~nm}$ and the lower panel the volume depolarization ratio. The smoothed lidar image is superimposed on the UAS flight track (black). Periods of sampling are indicated in red (numbers 24 to 29 in panel b). The numbers above the sampling period in panel a) give the INP concentration in $\operatorname{std~}^{-1}$ at $-30^{\circ} \mathrm{C}$ and $135.4 \%$ ice saturation. Altitude is given in meters above ground level relative to the location of the lidar in Nicosia (180 m a.s.1.). The red rectangle refers to the time periods investigated in Figs. 15, 16, and 17.

\subsection{Case study: major dust event of 9 April}

On 9 April the highest concentration of both dust and INPs was observed during the campaign (Fig. 10). Therefore, we present an in-depth analysis of this day.

Figure 14 depicts vertical profiles of the four flights of that day together with the time series of the attenuated backscatter and volume depolarization profile measured by lidar. The first two flights were performed with Cruiser, the last two with Skywalker X8. Figure 14a shows the smoothed attenuated backscatter signal at $1064 \mathrm{~nm}$ of the lidar measurement in Nicosia, $30 \mathrm{~km}$ away from the UAS airfield. Most of the sampling altitudes (red) matched the layer of high backscattering (yellow and red colors) containing mineral dust. The dust layer was located well above $1 \mathrm{~km}$ during the night and descended to below $1 \mathrm{~km}$ in the morning hours, where it stayed after 09:00 UTC. Its vertical extent also shrank considerably between 04:00 and 09:00 UTC. The lower panel of Fig. 14 shows the volume depolarization ratio. A high depolarization ratio (yellow and red colors) indicates the presence of non-spherical particles such as mineral dust. The concentration of INPs ( $\operatorname{std~L}^{-1}$ ) along the horizontal sampling tracks (red lines) is indicated by numbers (Fig. 14a). Most, but not all of the INP concentrations appear in reasonable agreement with the lidar observations: high INP concentrations coincide with high backscatter coefficients and high depolarization ratios. Note that sample 28 (second to last) showed such 

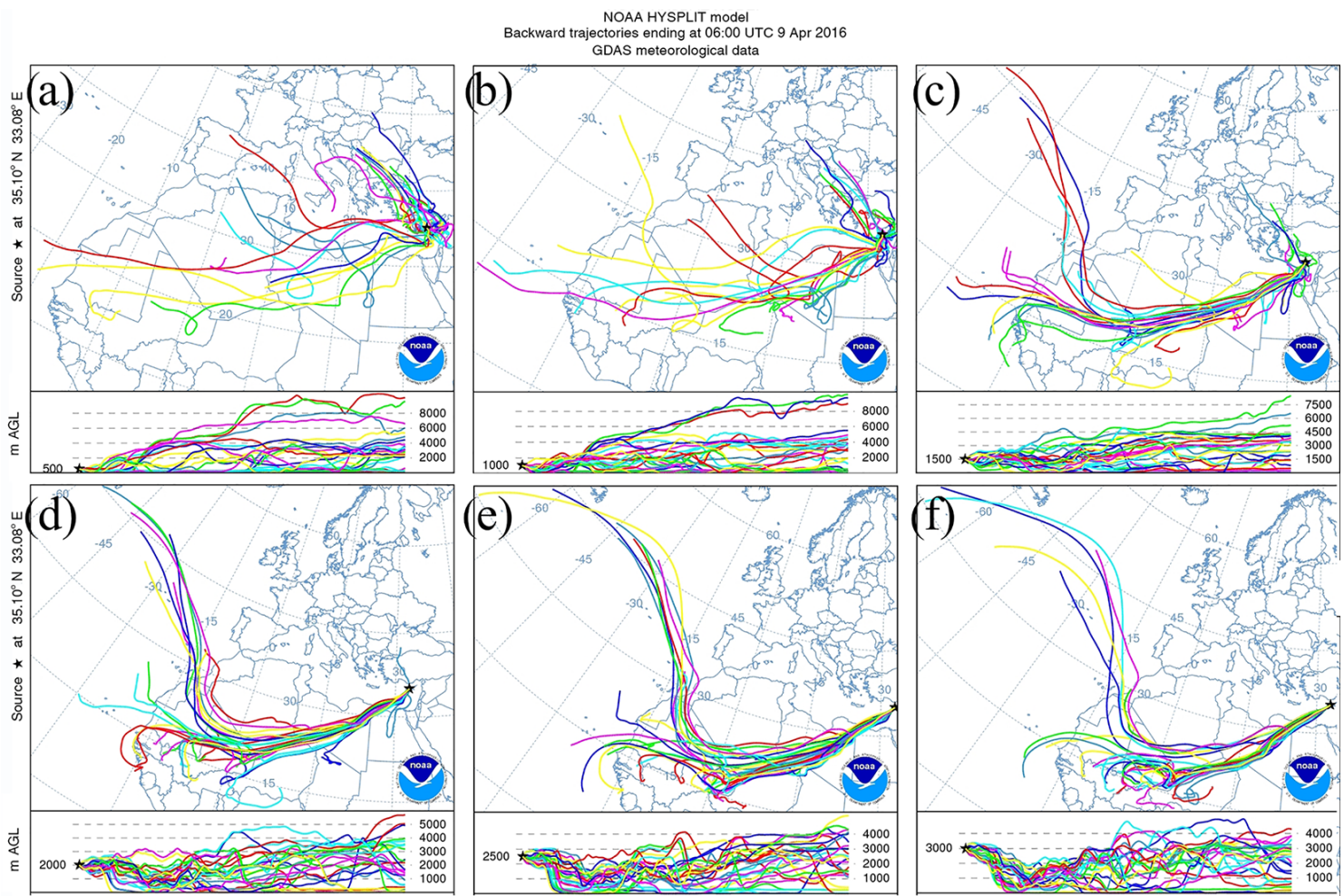

Figure 15. Ensembles of 27 seven-day HYSPLIT backward trajectories (Stein et al., 2015; Rolph, 2016) for the starting heights of 500 (a), 1000 (b), 1500 (c), 2000 (d), 2500 (e), and 3000 (f) m a.g.l. calculated for the UAS airfield on 9 April, 06:00 UTC.

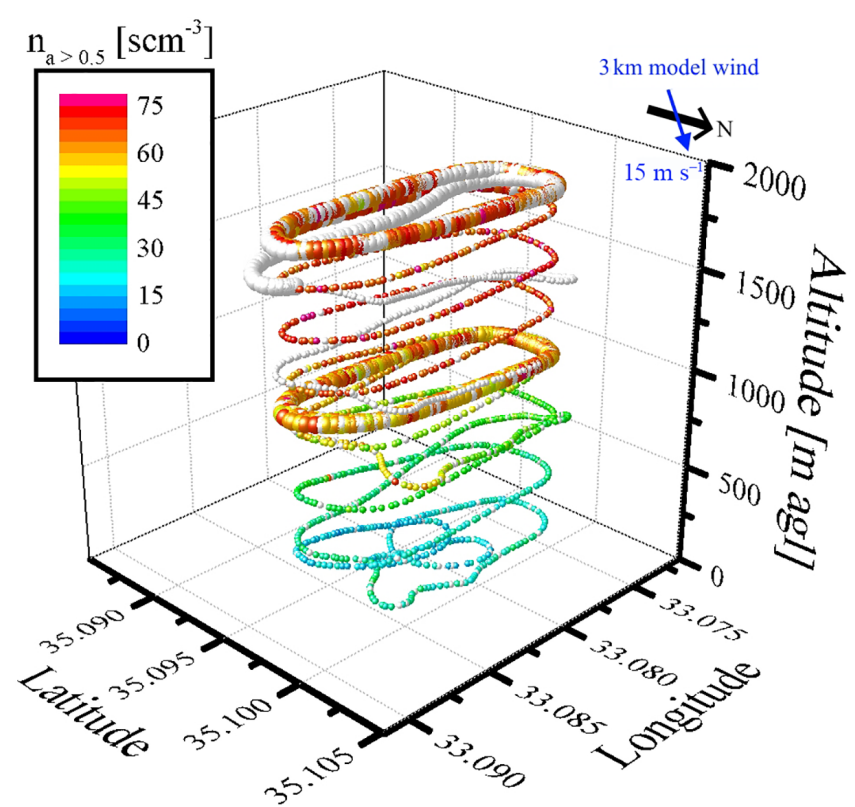

Figure 16. Flight track of the first Cruiser flight on 9 April. Colored spheres give the total number concentration of particles larger than $0.5 \mu \mathrm{m}$ (white: no measurement available). Larger-sized spheres indicate when sampling was carried out. The $3000 \mathrm{~m}$ wind at 06:00 UTC from DREAM (Movie S1) is given by the blue arrow. high ice activation even at $-25^{\circ} \mathrm{C}\left(180\right.$ INPs std $\left.\mathrm{L}^{-1}\right)$ that no measurement could be conducted at $-30^{\circ} \mathrm{C}$. This is rather surprising since the sampling altitude was seemingly well above the maximum of the actual dust layer (500 to $1000 \mathrm{~m}$ ). The depolarization signal (Fig. 14b), on the other hand, still showed a signal of medium to high strength for a broad range of altitudes up to $3 \mathrm{~km}$, suggesting that a considerable amount of mineral dust might have been collected. In fact, no depolarization ratio from any other day corresponding to the time or altitude of the samplings was found to be higher. Furthermore, we cannot rule out that the observed differences might have been caused by a heterogeneity in the dust spatial distribution between the two different operational sites.

The following paragraphs focus on the first Cruiser flight (red rectangle of Fig. 14, samples 24 and 25) of 9 April. HYSPLIT ensembles of backward air mass trajectories reaching the UAS airfield at elevation levels between 500 and $3000 \mathrm{~m}$ above ground on 9 April, 06:00 UTC, are shown in Fig. 15. For every $500 \mathrm{~m}$ a new plot is shown (a to f). The ensemble option of the HYSPLIT model computes each member of the ensemble by varying the initial meteorological starting condition of the model. Therefore, this method can be used to estimate how likely it is that an air mass of a specific time and place was transported from a certain region. Virtually all members of the ensemble of 27 trajectories ending at an elevation of $1500 \mathrm{~m}$ above ground or higher ( $\mathrm{c}$ to 
f) passed over the Sahara. Furthermore, the individual paths show very little spreading, suggesting that it is very likely that the air masses traveled in the given direction. For $1000 \mathrm{~m}$ and especially $500 \mathrm{~m}$, the trajectories diverged more strongly, with only 63 and $37 \%$ of the trajectories passing over northern Africa, respectively. This would suggest that sample 24 (05:30 to 05:41 UTC, mean alt. $1814 \mathrm{~m}$ a.g.l.) was very likely influenced by mineral dust transported from the Sahara and sample 25 (05:48 to 05:58 UTC, $1006 \mathrm{~m}$ a.g.1.) was likely influenced by mineral dust transported from the Sahara.

These findings agree with the lidar measurements discussed above and are supported by the high concentration of large particles measured by OPC, which was the highest of all flights. The latter translates also into the highest INP concentrations predicted (see Fig. 12) when the parameterizations are applied to these high $n_{a>0.5}$ values. The vertical profile and size spectra of $n_{a>0.5}$ during the flight are shown in Figs. 16 and 17. In Fig. 16 the three-dimensional flight track is plotted along with the color-coded aerosol number concentration measured with the OPC. It illustrates a typical flight routine.

Right after takeoff the Cruiser UAS was set to ascent mode. While spiraling up, the UAS accelerated up to its maximum speed. The aerosol concentration for particles $d>0.5 \mu \mathrm{m}$ increased from about $15 \mathrm{~cm}^{-3}$ at ground level to $50 \mathrm{~cm}^{-3}$ at $1 \mathrm{~km}$ and remained more or less constant until Cruiser reached the maximum altitude (Fig. 17c). These measurements agree well with the aerosol particle concentration retrieved from lidar in Nicosia by the method introduced in Mamouri and Ansmann (2016) $(R=0.96$ for $n=19$ bins of $100 \mathrm{~m}$ averages; OPC measurements: 05:05 to 05:55 UTC; lidar observation period: 06:50 to 07:00 UTC). Figure $17 \mathrm{c}$ also features the INP concentrations from the samples 24 and 25 and the INP concentration profile based on $n_{a>0.5}$ from lidar and OPC observations and the D15 parameterization with best-fitting parameters from Fig. 12d. Figure 17d depicts the aerosol size distribution. Above $500 \mathrm{~m}$ the number of particles as large as $2 \mu \mathrm{m}$ clearly increased, confirming the presence of a layer of mineral dust. Air temperature was stable at about 23 to $25^{\circ} \mathrm{C}$ in the lower $500 \mathrm{~m}$, from where it decreased linearly with altitude at a rate of $-8{ }^{\circ} \mathrm{C} \mathrm{km}^{-1}$ (Fig. 17b). The relative humidity showed a dry layer between 0.2 and $1 \mathrm{~km}$ and a more humid layer above (Fig. 17a). As soon as the desired elevation was hit (1800 $\mathrm{m}$ a.g.l.), the electrostatic sampling process started automatically for $10 \mathrm{~min}$. The UAS took an oval-shaped course (Fig. 16), while maintaining the altitude until the sampling ended. After sampling was completed the UAS descended to the second pre-set height (1000 ma.g.1.) where the sampling process was repeated.

\subsection{Electron microscopy of aerosol particles}

After the ice nucleation analysis in FRIDGE, two selected Si wafers (sample nos. 25 and 39) were analyzed with SEM

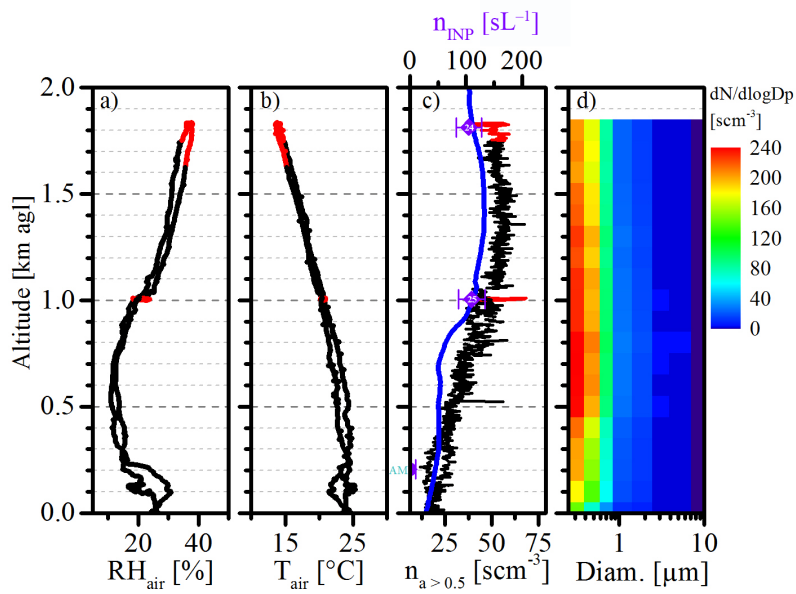

Figure 17. Vertical profiles of the first Cruiser flights on 9 April: (a) relative humidity and (b) temperature. Panel (c) shows number concentration (black line) $n_{a>0.5}$ of particles with $d>0.5 \mu \mathrm{m}$ measured by OPC onboard UASs (lower scale) as well as INP concentration (upper scale) derived from $n_{a>0.5}$ using the parameterization from Fig. 12d. Blue line: $n_{a>0.5}$ derived from lidar backscatter (lower scale) as well as INP concentration (upper scale) derived from $n_{a>0.5}$ using the parameterization from Fig. 12d. The INP measurements at $T=-30{ }^{\circ} \mathrm{C}$ of the samples 24 and 25 are given by purple diamonds; data from the ground station are labeled with AM. Altitude is given in meters above ground level relative to the location of the UAS airfield (327 $\mathrm{m}$ a.s.l.). The INP sampling interval is indicated in red. Panel (d) shows that the average aerosol size distribution is binned into $100 \mathrm{~m}$ intervals.

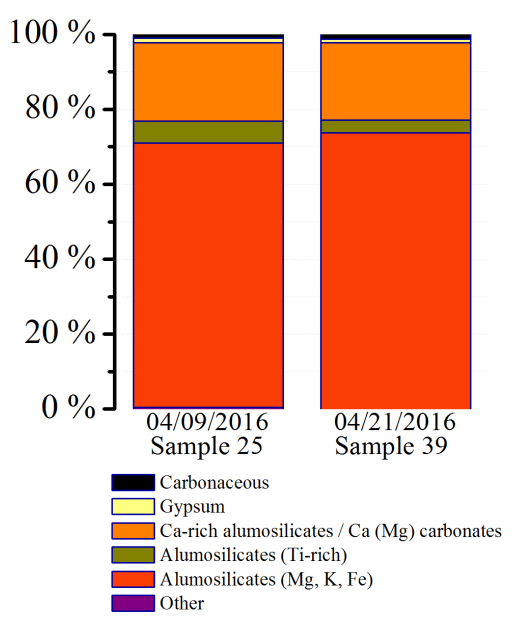

Figure 18. Chemical composition of single aerosol particles from electron microscopy of sample 25 (9 April) and sample 39 (21 April).

equipped with an EDX for the elemental composition and morphology of the individual aerosol particles. Sample 25 was from the major dust event (9 April) and sample 39 from the second intermediate dust event (21 April). More than 1000 individual particles with diameters $>400 \mathrm{~nm}$ were ana- 
lyzed (sample 25: 401 particles; sample 39: 628 particles). Overall, the chemical composition of the ambient aerosol sampled in the different dust events is very similar (Table 3, Fig. 18). For both samples around $99 \%$ of the analyzed particles were determined to be Saharan dust. In addition, a small number of $\mathrm{Ca}$ sulfates and carbonaceous particles was found. The Saharan dust particle category includes a main aluminosilicate group, Ti-rich aluminosilicates, and Ca-rich particles, which are either $\mathrm{Ca}(\mathrm{Mg})$ carbonates or mixtures of $\mathrm{Ca}$ carbonates with aluminosilicates. Furthermore, for both cases about $20 \%$ carbonates was found, which are a good tracer for dust particles that have source regions in the north Sahara (Scheuvens et al., 2013, cf. Sect. 3.1 and the Movie S1). From the present SEM analysis we cannot draw conclusions on the chemical composition and nature of INPs, which make only a $10^{-3}$ to $10^{-5}$ fraction of the randomly selected particles on a wafer. Nevertheless, given the predominance of Saharan dust particles in those two samples, it seems likely that mineral dust particles also formed the majority of INPs. Of course, it cannot be excluded that the ice nucleating activity of the individual mineral dust particles will also be affected by minor or trace compounds present as thin surface coatings or small heterogeneous inclusions, which are hardly detectable in SEM. For example, Conen et al. (2011) concluded from soil dust measurements in the range of -4 to $-15^{\circ} \mathrm{C}$ that the carbon content or biological residues within dust samples can define their ice nucleation properties. Similarly, Tobo et al. (2014) underlined the significance of organic matter in soil dusts as INPs in mixed-phase clouds at temperatures warmer than $-36^{\circ} \mathrm{C}$.

\section{Summary and conclusions}

The atmosphere over Cyprus during the INUIT, BACCHUS, and ACTRIS joint experiment was dominated by advection of dust in the lower and middle troposphere from North Africa, which coincided with high concentrations of INPs. At ground level, INP concentrations were an order of magnitude lower than aloft, pointing to relatively weak local marine and terrestrial sources from Cyprus. From these pronounced vertical profiles, we conclude that in atmospheric environments that are affected by the large dust sources of the globe, INP measurements performed at ground level will be only of limited significance for the situation several kilometers aloft at cloud level, for which this information is needed. Although the situation encountered by us over the Mediterranean Sea must not be generalized, it is well known as a climatological feature that desert dust regularly travels over distances of thousands of kilometers in this altitude range (Prospero, 1999; Liu et al., 2008).

Several events of long-range transport of Saharan mineral dust with varying intensity were registered during the campaign. The INP concentration followed various dust proxy parameters and correlated well with the number of large aerosol particles $(d>0.5 \mu \mathrm{m})$ measured in-flight as well as with lidar observations and the dust mass modeled by DREAM. The ice-active site density of the aerosol encountered during the flights compared reasonably well with published data from the Sahara (Boose et al., 2016). SEM analysis of samples taken during the two strongest dust events of the campaign identified about $99 \%$ of the individual aerosol particles with diameters above $400 \mathrm{~nm}$ as dust from the northern Sahara. Concomitant with the strongest dust event, the INP concentrations reached a peak value of more than 100 active ice nuclei per liter air. The measurements allow no conclusion as to whether it is dust that actively nucleates ice or particles that are admixed and travel with the dust.

These are the first INP measurements obtained with the technology of unmanned aircraft systems. The combination of a UAS and an offline sampling system with subsequent laboratory analysis of INPs is novel and represents a promising alternative to measurements on a research aircraft. Aside from the simplicity as compared to a conventional aircraft mission, the main advantage of the combination of UAS and INP sampling device is its versatility. We were able to adapt rapidly to the current meteorological situation, thereby scheduling flights to accurately target specific small- to medium-scale phenomena such as dense layers of dust. However, admittedly, the small to medium-sized UASs have certain limitations in terms of maximum payload, top elevation, flight time, spatial coverage, and meteorological conditions (wind speed or precipitation), as well as flight restrictions due to the safety of air traffic.

Nevertheless, we encourage other groups to consider UASs as an option to carry out measurements of ice nucleating particles, whether with a similar setup as presented here or in a different configuration. This tool could broaden the few existing sets of non-surface-based INP observations significantly for regions all over the world.

Data availability. The INP data used in this study can be accessed through the BACCHUS database of INP observations. The database is accessible to members only but membership is free: http://www. bacchus-env.eu/in/. The INP dataset of this study can be reached through this link: http://www.bacchus-env.eu/in/info.php?id=72. If you are interested in the accompanying datasets (lidar observations, DREAM model data, etc.), please contact the authors.

\section{The Supplement related to this article is available online at doi:10.5194/acp-17-4817-2017-supplement.}

Competing interests. The authors declare that they have no conflict of interest.

Acknowledgements. The research leading to these results has received funding from the European Union's Seventh Framework 
Programme (FP7/2007-2013) project BACCHUS under grant agreement no. 603445 and the Deutsche Forschungsgemeinschaft (DFG) under the Research Unit FOR 1525 (INUIT). This campaign was performed at the Cyprus Atmospheric Observatory (CAO), which is part of the ACTRIS2 project that has received funding from the European Union's Horizon 2020 research and innovation programme under grant agreement no. 654109. Mihalis Vrekoussis acknowledges support from the DFG-Research Center/Cluster of Excellence "The Ocean in the Earth System-MARUM". Eleni Marinou acknowledges the Stavros Niarchos Foundation for its support. The support by the international Research Institute for Climate and Society, Columbia University, Palisades, NY, with meteorological data and software is gratefully acknowledged. We thank SNO PHOTONS/AERONET from INSU/CNRS/University of Lille, France, AERONET-Europe/ACTRIS Calibration Center, and the AERONET team at GSFC for their kind cooperation. The Department of Labour Inspection (DLI, Ministry of Labour, Welfare, and Social Insurance) is thanked for the provisions of ground-based weather and PM data at CAO. The provision of the HYSPLIT transport and dispersion model from the NOAA Air Resources Laboratory is gratefully acknowledged.

Edited by: B. Ervens

Reviewed by: two anonymous referees

\section{References}

Althausen, D., Engelmann, R., Baars, H., Heese, B.. Ansmann, A., Müeller, D., and Komppula, M.: Portable Raman Lidar PollyXT for Automated Profiling of Aerosol Backscatter, Extinction, and Depolarization, J. Atmos. Ocean. Tech., 26, 2366-2378, doi:10.1175/2009JTECHA1304.1, 2009.

Ansmann, Wandinger, U., Riebesell, M., Weitkamp, U., and Michaelis, W.: Independent measurement of extinction and backscatter profiles in cirrus clouds by using a combined Raman elastic-backscatter lidar, Appl. Opt., 31, 7113-7131, doi:10.1364/AO.31.007113, 1992.

Atkinson, J. D., Murray, B. J., Woodhouse, M. T., Whale, T. F., Baustian, K. J., Carslaw, K. S., Dobbie, S., O'Sullivan, D., and Malkin, T. L.: The importance of feldspar for ice nucleation by mineral dust in mixed-phase clouds, Nature, 498, 355-358, doi:10.1038/nature12278, 2013.

Baars, H., Kanitz, T., Engelmann, R., Althausen, D., Heese, B., Komppula, M., Preißler, J., Tesche, M., Ansmann, A., Wandinger, U., Lim, J.-H., Ahn, J. Y., Stachlewska, I. S., Amiridis, V., Marinou, E., Seifert, P., Hofer, J., Skupin, A., Schneider, F., Bohlmann, S., Foth, A., Bley, S., Pfüller, A., Giannakaki, E., Lihavainen, H., Viisanen, Y., Hooda, R. K., Pereira, S. N., Bortoli, D., Wagner, F., Mattis, I., Janicka, L., Markowicz, K. M., Achtert, P., Artaxo, P., Pauliquevis, T., Souza, R. A. F., Sharma, V. P., van Zyl, P. G., Beukes, J. P., Sun, J., Rohwer, E. G., Deng, R., Mamouri, R.-E., and Zamorano, F.: An overview of the first decade of PollyNET: an emerging network of automated Raman-polarization lidars for continuous aerosol profiling, Atmos. Chem. Phys., 16, 5111-5137, doi:10.5194/acp-165111-2016, 2016.

Bates, T. S., Quinn, P. K., Johnson, J. E., Corless, A., Brechtel, F. J., Stalin, S. E., Meinig, C., and Burkhart, J. F.: Measurements of at- mospheric aerosol vertical distributions above Svalbard, Norway, using unmanned aerial systems (UAS), Atmos. Meas. Tech., 6, 2115-2120, doi:10.5194/amt-6-2115-2013, 2013.

Boose, Y., Sierau, B., García, M. I., Rodríguez, S., Alastuey, A., Linke, C., Schnaiter, M., Kupiszewski, P., Kanji, Z. A., and Lohmann, U.: Ice nucleating particles in the Saharan Air Layer, Atmos. Chem. Phys., 16, 9067-9087, doi:10.5194/acp-16-90672016, 2016.

Bundke, U., Nillius, B., Jaenicke, R., Wetter, T., Klein, H., and Bingemer, H.: The fast Ice Nucleus chamber FINCH, Atmos. Res., 90, 180-186, doi:10.1016/j.atmosres.2008.02.008, 2008.

Colomina, I., and Molina, P.: Unmanned aerial systems for photogrammetry and remote sensing: A review, ISPRS J. Photogramm., 92, 79-97, doi:10.1016/j.isprsjprs.2014.02.013, 2014.

Conen, F., Morris, C. E., Leifeld, J., Yakutin, M. V., and Alewell, C.: Biological residues define the ice nucleation properties of soil dust, Atmos. Chem. Phys., 11, 9643-9648, doi:10.5194/acp-119643-2011, 2011.

Corrigan, C. E., Roberts, G. C., Ramana, M. V., Kim, D., and Ramanathan, V.: Capturing vertical profiles of aerosols and black carbon over the Indian Ocean using autonomous unmanned aerial vehicles, Atmos. Chem. Phys., 8, 737-747, doi:10.5194/acp-8-737-2008, 2008.

Cziczo, D. J., Murphy, D. M., Hudson, P. K., and Thomson, D. S.: Single particle measurements of the chemical composition of cirrus ice residue during CRYSTAL-FACE, J. Geophys. Res., 109, D04201, doi:10.1029/2003JD004032, 2004.

DeMott, P. J., K. Sassen, M. R. Poellot, D. Baumgardner, D. C. Rogers, S. D. Brooks, A. J. Prenni, and Kreidenweis, S, M.: African dust aerosols as atmospheric ice nuclei, Geophys. Res. Lett., 30, ASC 1-1-ASC 1-4, doi:10.1029/2003GL017410, 2003.

DeMott, P. J., Cziczo, D. J., Prenni, A. J., Murphy, D. M., Kreidenweis, S. M., Thomson, D. S., Borys, R. and Rogers, D. C.: Measurements of the concentration and composition of nuclei for cirrus formation, P. Natl. Acad. Sci. USA, 100, 14655-14660, doi:10.1073/pnas.2532677100, 2003.

DeMott, P. J., Prenni, A. J., Liu, X., Kreidenweis, S. M., Petters, M. D., Twohy, C. H., Richardson, M. S., Eidhammer T., and Rogers, D. C.: Predicting global atmospheric ice nuclei distributions and their impacts on climate, P. Natl. Acad. Sci. USA, 107, 25, 11217-11222, doi:10.1073/pnas.0910818107, 2010.

DeMott, P. J., Prenni, A. J., McMeeking, G. R., Sullivan, R. C., Petters, M. D., Tobo, Y., Niemand, M., Möhler, O., Snider, J. R., Wang, Z., and Kreidenweis, S. M.: Integrating laboratory and field data to quantify the immersion freezing ice nucleation activity of mineral dust particles, Atmos. Chem. Phys., 15, 393-409, doi:10.5194/acp-15-393-2015, 2015.

DLI: Data from the Department of Labour Inspection (DLI) of the Ministry of Labour, Welfare and Social Insurance of Cyprus available at: http://www.airquality.dli.mlsi.gov.cy/ (last access: 5 December 2016).

Engelmann, R., Kanitz, T., Baars, H., Heese, B., Althausen, D., Skupin, A., Wandinger, U., Komppula, M., Stachlewska, I. S., Amiridis, V., Marinou, E., Mattis, I., Linné, H., and Ansmann, A.: The automated multiwavelength Raman polarization and water-vapor lidar PollyXT: the neXT generation, Atmos. Meas. Tech., 9, 1767-1784, doi:10.5194/amt-9-1767-2016, 2016. 
Georgii, H. W. and Kleinjung, E.: Relations between the chemical composition of atmospheric aerosol particles and the concentration of natural ice nuclei, J. Rech. Atmos., 3, 145-156, 1967.

Ginoux, P., Chin, M., Tegen, I., Prospero, J. M., Holben, B., Dubovik, O., and Lin, S.: Sources and distributions of dust aerosols simulated with the GOCART model, J. Geophys. Res., 106, 20255-20273, doi:10.1029/2000JD000053, 2001.

Holland, G. J., McGeer, T., amd Youngren, H.: Autonomous Aerosondes for Economical Atmospheric Soundings Anywhere on the Globe, B. Am. Meteorol. Soc., 73, 12, 1987-1998, doi:10.1175/1520-0477(1992)073<1987:AAFEAS>2.0.CO;2, 1992.

Hoose, C., Kristjánsson, J. E., Chen, J.-P., and Hazra, A.: A Classical-Theory-Based Parameterization of Heterogeneous Ice Nucleation by Mineral Dust, Soot, and Biological Particles in a Global Climate Model, J. Atmos. Sc., 67, 8, 2483-2503, doi:10.1175/2010JAS3425.1, 2010.

IPCC: Climate Change 2013: The Physical Science Basis, Contribution of Working Group I to the Fifth Assessment Report of the Intergovernmental Panel on Climate Change, edited by: Stocker, T. F., Qin, D., Plattner, G.-K., Tignor, M., Allen, S. K., Boschung, J., Nauels, A., Xia, Y., Bex V., and Midgley, P. M., Cambridge University Press, Cambridge, United Kingdom and New York, NY, USA, 1535 pp., doi:10.1017/CBO9781107415324, 2013.

IRI 2016: International Research Institute for Climate and Society, Climate Data Library, Columbia University, Palisades, N.Y., USA, available at: http://iridl.ldeo.columbia.edu/, (last access: 15 November 2016).

Isono, K.: On ice-crystal nuclei and other subsances found in snow crystals J. Meteorol., 12, 5, 456-462, doi:10.1175/15200469(1955)012<0456:OICNAO>2.0.CO;2, 1955.

Israelevich, P. L., Levin, Z., Joseph, J. H., and Ganor, E.: Desert aerosol transport in the Mediterranean region as inferred from the TOMS aerosol index, J. Geophys. Res., 107, 4572, doi:10.1029/2001JD002011, 2002.

Janjic, Z. I., Gerrity Jr., J. P., and Nickovic, S.: An Alternative Approach to Nonhydrostatic Modeling, Mon. Weather Rev., 129, 1164-1178, doi:10.1175/15200493(2001)129<1164:AAATNM>2.0.CO;2, 2001.

Janjic, Z. I.: A Nonhydrostatic Model Based on a New Approach, Meteorol. Atmos. Phys., 82, 271-285, doi:10.1007/s00703-0010587-6, 2003.

Janjic, Z., Janjic, T., and Vasic, R.: A class of conservative fourth order advection schemes and impact of enhanced formal accuracy on extended-range forecasts, Mon. Weather Rev., 139, 15561568, doi:10.1175/2010MWR3448.1, 2011

Jensen, E. J., Diskin, G., Lawson, R. P., Lance, S., Bui, T. P., Hlavka, D., McGill, M., Pfister, L., Toon, O. B., and Gao, R.: Ice nucleation and dehydration in the Tropical Tropopause Layer, P. Natl. Acad. Sci. USA, 110, 2041-2046, doi:10.1073/pnas.1217104110, 2012.

Kanji, Z., and the science team of the INUIT-BACCHUS-ACTRIS field campaign: in Cyprus 2016, in preparation, 2017.

Klein, H., Haunold, W., Bundke, U., Nillius, B., Wetter, T., Schallenberg, S., and Bingemer, H.: A new method for sampling of atmospheric ice nuclei with subsequent analysis in a static diffusion chamber, Atmos. Res., 96, 218-224, doi:10.1016/j.atmosres.2009.08.002, 2010.
Kumai, M.: Electron-microscopy study of snow-crystal nuclei, J. Meteorol., 8, 3, 151-156, doi:10.1175/15200469(1951)008<0151:EMSOSC>2.0.CO;2, 1951.

Liu, D., Wang, Z., Liu, Z., Winker, D., and Trepte, C.: A height resolved global view of dust aerosols from the first year CALIPSO lidar measurements, J. Geophys. Res., 113, D16214, doi:10.1029/2007JD009776, 2008.

Maki, L. R., Galyan, E. L., Chang-Chien, M.-M., and Caldwell, D. R.: Ice Nucleation Induced by Pseudomonas syringae, Appl. Microbiol., 28, 3, 456-459, 1974.

Mamouri, R. E. and Ansmann, A.: Fine and coarse dust separation with polarization lidar, Atmos. Meas. Tech., 7, 3717-3735, doi:10.5194/amt-7-3717-2014, 2014.

Mamouri, R.-E. and Ansmann, A.: Potential of polarization lidar to provide profiles of $\mathrm{CCN}$ - and INP-relevant aerosol parameters, Atmos. Chem. Phys., 16, 5905-5931, doi:10.5194/acp-16-59052016, 2016.

McGonigle, A. J. S., Aiuppa, A., Giudice, G., Tamburello, G., Hodson, A. J., and Gurrieri, S.: Unmanned aerial vehicle measurements of volcanic carbon dioxide fluxes, Geophys. Res. Lett., 35, L06303, doi:10.1029/2007GL032508, 2008.

Meyers, M., DeMott., P., and Cotton, W.: New Primary Ice-Nucleation Parameterizations in an Explicit Cloud Model, J. Appl. Meteor., 31, 708-721, doi:10.1175/15200450(1992)031<0708:NPINPI>2.0.CO;2, 1992.

Moulin, C., Lambert, E., Dayan, U., Masson, V., Ramonet, M., Bousquet, P., Legrand, M., Balkanski, Y. J., Guelle, W., Marticorena, B., Bergametti, G. and Dulac, F.: Satellite climatology of African dust transport in the Mediterranean atmosphere, J. Geophys. Res., 103, 13137-13144, doi:10.1029/98JD00171, 1998.

Mülmenstädt, J., Sourdeval, O., Delanoë, J., and Quaas, J.: Frequency of occurrence of rain from liquid-, mixed-, and ice-phase clouds derived from A-Train satellite retrievals, Geophys. Res. Lett., 42, 6502-6509, doi:10.1002/2015GL064604, 2015.

Nickovic, S., Papadopoulos, A., Kakaliagou, O., and Kallos, G.: A model for prediciton of desert dust cycle in the atmosphere, J. Geophys. Res., 106, 18113-18129, doi:10.1029/2000JD900794, 2001.

Nickovic, S.: Distribution of dust mass over particle sizes: impacts on atmospheric optics, Forth ADEC Workshop - Aeolian Dust Experiment on Climate Impact, 26-28 January, Nagasaki, Japan, 357-360, 2005.

Niemand, M., Möhler, O., Vogel, B., Vogel, H., Hoose, C., Connolly, P., Klein, H., Bingemer, H., DeMott, P. and Skrotzki, J.: A particle-surface-area-based parameterization of immersion freezing on desert dust particles, J. Atmos. Sci., 69, 3077-3092, doi:10.1175/JAS-D-11-0249.1, 2012.

O’Sullivan, D., Murray, B. J., Ross, J. F., Whale, T. F., Price, H. C., Atkinson, J. D., Umo, N. S., and Webb, M. E.: The relevance of nanoscale biological fragments for ice nucleation in clouds, Sci. Rep., 5, 8082, doi:10.1038/srep08082, 2015.

O'Sullivan, D., Murray, B. J., Ross, J. F., and Webb, M. E.: The adsorption of fungal ice-nucleating proteins on mineral dusts: a terrestrial reservoir of atmospheric ice-nucleating particles, Atmos. Chem. Phys., 16, 7879-7887, doi:10.5194/acp-16-78792016, 2016.

Pejanovic, G., Nickovic, S., Vujadinovic, M., Vukovic, A., Djurdjevic, V., and Dacic, M.: Atmospheric deposition of minerals in dust over the open ocean and possible consequences on climate, 
WCRP OSC Climate Research in Service to Society, 24-28 October 2011, Denver, CO, USA, 2011.

Pey, J., Querol, X., Alastuey, A., Forastiere, F., and Stafoggia, M.: African dust outbreaks over the Mediterranean Basin during 2001-2011: PM10 concentrations, phenomenology and trends, and its relation with synoptic and mesoscale meteorology, Atmos. Chem. Phys., 13, 1395-1410, doi:10.5194/acp-13-13952013, 2013.

Pratt, K. A., DeMott, P. J., French, J. R:, Wang, Z., Westphal, D. L., Heymsfield, A. J., Twohy, C. H., Prenni, A. J., and Prather, K. A.: In situ detection of biological particles in cloud ice-crystals, Nat. Geosci., 2, 398-401, doi:10.1038/NGEO521, 2009.

Prenni, A. J., DeMott, P. J., Rogers, D. C., Kreidenweis, S. M., McFarquhar, G. M., Zhang, G., and Poellot, M. R.: Ice nuclei characteristics from M-PACE and their relation to ice formation in clouds, Tellus, 61B, 436-448, doi:10.1111/j.16000889.2009.00415.x, 2009.

Prenni, A. J., Petters, M. D., Kreidenweis, S. M., Heald, C. L., Martin, S. T., Artaxo, P., Garland, R. M., Wollny A. G., and Pöschl, U.: Relative roles of biogenic emissions and Saharan dust as ice nuclei in the Amazon basin, Nat. Geosci., 2, 402-405, doi:10.1038/ngeo517, 2009.

Prospero, J. M.: Long-range transport of mineral dust in the global atmosphere: Impact of African dust on the environment of the southeastern United States, P. Natl. Acad. Sci., 96, 7, 3396-3403, doi:10.1073/pnas.96.7.3396, 1999.

Querol X., Pey, J., Pandolfi, M., Alastuey, A., Cusack, M., Pérez, N., Moreno, T., Viana, M., Mihalopoulos, N., Kallos, G., and Kleanthous, S.: African dust contributions to mean ambient PM10 mass-levels across the Mediterranean Basin, Atmos. Environ., 43, 4266-4277, doi:10.1016/j.atmosenv.2009.06.013, 2009.

Reuder, J., Brisset, P., Jonassen, M., Müller, M., and Mayer, S.: The Small Unmanned Meteorological Observer SUMO: A new tool for atmospheric boundary layer research, Meteorol. Z., 18, 2, 141-147, doi:10.1127/0941-2948/2009/0363, 2009.

Roberts, G. C., Ramana, M. V., Corrigan, C., Kim, D., and Ramanathan, V.: Simultaneous observations of aerosol-cloudalbedo interactions with three stacked unmanned aerial vehicles, P. Natl. Acad. Sci. USA, 105, 21, 7370-7375, doi:10.1073/pnas.0710308105, 2007.

Rogers, D. C., DeMott, P. J., Kreidenweis, S. M., and Chen, Y.: A continuous-flow diffusion chamber for airborne measurements of ice nuclei, J. Atmos. Ocean. Tech., 18, 5, 725-741, doi:10.1175/1520-0426(2001)018<0725:ACFDCF>2.0.CO;2, 2001.

Rogers, D. C., DeMott, P. J., and Kreidenweis, S. M.: Airborne measurements of tropospheric ice-nucleating aerosol particles in the Arctic spring, J. Geophys. Res., 106, 15053-15063, doi:10.1029/2000JD900790, 2001.

Rolph, G. D.: Real-time Environmental Applications and Display sYstem (READY) Website, available at: http://ready.arl.noaa.gov (last access: 4 August 2016), NOAA Air Resources Laboratory, Silver Spring, MD, 2016.
Scheuvens, D., Schütz, L., Kandler, K., Ebert, M. and Weinbruch, S.: Bulk composition of northern African dust and its source sediments - A compilation, Earth-Sci. Rev., 116, 170 194, doi:10.1016/j.earscirev.2012.08.005, 2013.

Schnell, R. C. and Vali, G.: World-wide Source of Leaf-derived Freezing Nuclei, Nature, 246, 212-213, doi:10.1038/246212a0, 1973.

Schrod, J., Danielczok, A., Weber, D., Ebert, M., Thomson, E. S., and Bingemer, H. G.: Re-evaluating the Frankfurt isothermal static diffusion chamber for ice nucleation, Atmos. Meas. Tech., 9, 1313-1324, doi:10.5194/amt-9-1313-2016, 2016.

Stein, A. F., Draxler, R. R., Rolph, G. D., Stunder, B. J. B., Cohen, M. D., and Ngan, F.: NOAAs HYSPLIT Atmospheric Transport and Dispersion Modeling System, B. Am. Meteorol. Soc., 96, 2059-2077, doi:10.1175/BAMS-D-14-00110.1, 2015.

Tobo, Y., Prenni, A. J., DeMott, P. J., Huffman, J. A., McCluskey, C. S., Tian, G., Pöhlker, C., Pöschl, U., and Kreidenweis, S. M.: Biological aerosol particles as a key determinant of ice nuclei populations in a forest ecosystem, J. Geophys. Res. Atmos., 118, 10100-10110, doi:10.1002/jgrd.50801, 2013.

Tobo, Y., DeMott, P. J., Hill, T. C. J., Prenni, A. J., SwobodaColberg, N. G., Franc, G. D., and Kreidenweis, S. M.: Organic matter matters for ice nuclei of agricultural soil origin, Atmos. Chem. Phys., 14, 8521-8531, doi:10.5194/acp-14-8521-2014, 2014.

Vali, G., Christensen, M., Fresh, R. W., Galyan, E. L., Maki, L. R. and Schnell, R. C.: Biogenic Ice Nuclei, Part II: Bacterial Sources, J. Atmos. Sci., 33, 1565-1570, doi:10.1175/15200469(1976)033<1565:BINPIB>2.0.CO;2, 1976.

Vali, G., DeMott, P. J., Möhler, O., and Whale, T. F.: Technical Note: A proposal for ice nucleation terminology, Atmos. Chem Phys., 15, 10263-10270, doi:10.5194/acp-15-10263-2015, 2015.

Wandinger, U.: Lidar - Range-Resolved Optical Remote Sensing of the Atmosphere, Springer Series in Optical Sciences, edited by: Weitkamp, C., Springer Berlin/Heidelberg, 102, 1-18, 2005.

Watts, A. C., Ambrosia, V. G., and Hinkley, E. A.: Unmanned Aircraft Systems in Remote Sensing and Scientific Research: Classification and Considerations of Use, Remote Sens., 4, 1671-1692, doi:10.3390/rs4061671, 2012.

Wegener, A.: Thermodynamik der Atmosphäre, Barth, Leipzig, 331 pp., 1911.

Wex, H., Augustin-Bauditz, S., Boose, Y., Budke, C., Curtius, J., Diehl, K., Dreyer, A., Frank, F., Hartmann, S., Hiranuma, N., Jantsch, E., Kanji, Z. A., Kiselev, A., Koop, T., Möhler, O., Niedermeier, D., Nillius, B., Rösch, M., Rose, D., Schmidt, C., Steinke, I., and Stratmann, F.: Intercomparing different devices for the investigation of ice nucleating particles using Snomax ${ }^{\circledR}$ as test substance, Atmos. Chem. Phys., 15, 14631485, doi:10.5194/acp-15-1463-2015, 2015. 